January 2015

\title{
The Supreme Court's New Approach to Personal Jurisdiction
}

Bernadette Bollas Genetin

The University of Akron School of Law

\section{Recommended Citation}

Bernadette Bollas Genetin, The Supreme Court's New Approach to Personal Jurisdiction, 68 SMU L. REV. 107 (2015)

https://scholar.smu.edu/smulr/vol68/iss1/4

This Article is brought to you for free and open access by the Law Journals at SMU Scholar. It has been accepted for inclusion in SMU Law Review by an authorized administrator of SMU Scholar. For more information, please visit http://digitalrepository.smu.edu. 


\title{
The Supreme Court's New Approach to Personal Jurisdiction
}

\author{
Bernadette Bollas Genetin*
}

\section{INTRODUCTION}

$\mathrm{T}$

IHE Supreme Court's two most recent opinions on personal jurisdiction usher in a new era in the law of general and specific personal jurisdiction. In Daimler AG v. Bauman, ${ }^{1}$ the Supreme Court narrowed the scope of general jurisdiction, making it available primarily in an individual's domicile and a corporation's state of incorporation and principal place of business. ${ }^{2}$ In the specific jurisdiction case of Walden $v$. Fiore, the Court, correspondingly, turned away from a strict purposeful availment approach and toward an approach that permits consideration of the relation of both the defendant and the litigation to the forum state. ${ }^{3}$ If the Court stays this course, specific jurisdiction could assume the central role in personal jurisdiction analysis that Bauman claims for it. ${ }^{4}$ The Court, however, must resist the temptation-evident in Walden $v$. Fiore itself-to substitute fictions designed to limit the reach of specific jurisdiction ${ }^{5}$ for the more functional, reasonableness analysis permitted by International Shoe. ${ }^{6}$ This Article concludes with a version of an interest analysis that will allow specific jurisdiction to play the central role that it must, given the Court's narrowing of general jurisdiction. ${ }^{7}$

Three years ago, in Goodyear Dunlop Tires Operations, S.A. v. Brown,

* Bernadette Bollas Genetin, Associate Professor, The University of Akron School of Law. I thank Marian J. Kousaie for research support.

1. 134 S. Ct. 746 (2014). text.

2. Id. at 760-61 \& nn.19-20; see also infra notes 13 and 262-279, and accompanying

3. Walden v. Fiore, 134 S. Ct. 1115, 1125-26 (2014).

4. Bauman, 134 S. Ct. at 755 (stating that specific jurisdiction "has become the centerpiece of modern jurisdiction theory") (quoting Goodyear Dunlop Tires Operations, S.A. v. Brown, 131 S. Ct. 2846, 2854 (2011) (quoting in turn Mary Twitchell, The Myth of General Jurisdiction, 101 Harv. L. Rev. 610, 628 (1988)).

5. See Albert A. Ehrenzweig, Pennoyer is Dead. Long Live Pennoyer, 30 Rocky Mtn. L. Rev. 285, 291-92 (1958) (advocating, at least for individual defendants, a continuation of Pennoyer's power theory of jurisdiction); see also Charles W. "Rocky" Rhodes, Nineteenth Century Personal Jurisdiction Doctrine in a Twenty-First Century World, 64 FLA. L. REv. 387, 406-07 (2012) (noting that, although International Shoe rejected the fiction of implied consent, the Court ultimately substituted the construct of purposeful availment, which required "an analogous evaluation of the defendant's underlying activities in the forum").

6. Int'l Shoe Co. Washington, 326 U.S. 310, 324, 326 (1945); see infra notes 117-147, and accompanying text.

7. E.g., Rhodes, supra note 5, at 433 (concluding, after Goodyear, that, "in light of the diminished scope of general jurisdiction, specific jurisdiction must reach to nonresi- 
the Supreme Court began the move toward its new doctrinal approach. ${ }^{8}$ The Goodyear Court held that general jurisdiction based on the extent and nature of a corporate defendant's forum contacts is available only when a defendant's activities are so "continuous and systematic" that the defendant is "essentially at home" in the forum state. ${ }^{9}$ The potential narrowing of general jurisdiction was important and consonant with persistent scholarly commentary. Broadly permitting general jurisdiction when a defendant has continuous and systematic forum contacts multiplies the forums in which a defendant may be sued on claims unrelated to its instate activity, may permit a plaintiff unwarranted forum choice, and has impeded U.S. entry into international treaties. ${ }^{10}$ Some lower courts, nevertheless, interpreted Goodyear broadly and continued to permit general jurisdiction based on a defendant's continuous and systematic forum contact. ${ }^{11}$ The Supreme Court's recent decision in Daimler AG v. Bauman completed the narrowing of general jurisdiction. Bauman indicates that general jurisdiction will be available primarily in a corporate defendant's state of incorporation and principal place of business. ${ }^{12}$ It will not be available based on a defendant's "continuous and systematic" forum contact, absent exceptional circumstances. ${ }^{13}$

The Court's restriction of general jurisdiction, though long recommended by commentators, raises real concerns. ${ }^{14}$ A limited scope for gen-

dents causing harms or effects in the forum unless the jurisdictional assertion will be unduly burdensome"); Twitchell, supra note 4, at 652 .

8. See Goodyear Dunlap Operations, S.A. v. Brown, 131 S. Ct. 2846 (2011).

9. Id. at 2851, 2856-57.

10. E.g., Daimler AG v. Bauman, 134 S. Ct. 746, $762-63$ (2014); see also, e.g., Patrick J. Borchers, The Problem with General Jurisdiction, 2001 U. CHI. LEgal F. 119, 119, 123-24 (2001); Lea Brilmayer et al., A General Look at General Jurisdiction, 66 Tex. L. Rev. 721, 725-26 (1988); Walter W. Heiser, A "Minimum Interest" Approach to Personal Jurisdiction, 35 Wake Forest L. Rev. 915, 924-25, 946-47 (2000); Allan R. Stein, The Meaning of "Essentially at Home" in Goodyear Dunlop, 63 S. C. L. Rev. 527, 528, 532, 540-41 (2012); Twitchell, supra note 4, at 670-72; Arthur T. von Mehren and Donald T. Trautman, Jurisdiction to Adjudicate: A Suggested Analysis, 79 Harv. L. Rev. 1121, 1141-44 (1966).

11. See, e.g., Susanna Sherry, Don't Answer That! Why (and How) the Supreme Court Should Duck the Issue in DaimlerChrysler AG v. Bauman, 66 VAnd. L. Rev. En BanC 111, 118-19 \& n.32 (2013) (citing J.B. ex rel. Benjamin v. Abbott Labs., Inc., 2013 WL 452807 (N.D. Ill., Feb. 6, 2013); Ashbury Int'l Group v. Cadex Defence, Inc., 2012 WL 4325183 (W.D. Va., Sept. 20, 2012); and McFadden v. Fuyao N. America Inc., 2012 WL 1230046 (E.D. Mich., Apr. 12, 2012)).

12. Bauman, 134 S. Ct. at 746, 760-61 \& nn.19-20. See also infra notes 262-279, and accompanying text.

13. Bauman, $134 \mathrm{~S}$. Ct. at $760-61$. The Bauman Court did provide space for general jurisdiction outside its paradigmatic instances, but a discussion of that issue is beyond the scope of this article.

14. E.g., Brilmayer, et al, supra note 10 , at $726,742-43$, 782; Stein, supra note 10 , at 532; Twitchell, supra note 4, at 667-70 (concluding that the "best approach to general jurisdiction" is to limit it to a defendant's "home base" and, thus, recognize its "most essential function," that of "providing one forum where a defendant may always be sued"); von Mehren \& Trautman, supra note 10, at 1139, 1141-44, 1177-79; see also Mary Twitchell, Why We Keep Doing Business with Doing-Business Jurisdiction, 2001 U. ChI. Legal F. 171, 203-14 (exploring methods of reducing doing-business, general jurisdiction; assessing the likelihood of their adoption; and arguing, at least, for a more restricted general jurisdiction over foreign corporations). 
eral jurisdiction was supposed to have followed, rather than preceded, an expansion of specific jurisdiction. ${ }^{15}$ Confining general jurisdiction principally to a corporation's state of incorporation and principal place of business and recognizing only limited instances of specific jurisdiction would mean that, in many cases, the plaintiff would have to pursue a corporate defendant in its state of incorporation or principal place of business, or the plaintiff would have to forego suit. In a world in which corporations can and do operate regionally, nationally, and internationally, this would be unacceptable, and it is not required by the Due Process Clause.

Commentators had predicted, post-International Shoe, that specific jurisdiction would flower and general jurisdiction would wither. ${ }^{16}$ Courts would predominantly hale defendants to foreign jurisdictions based on "specific" jurisdiction, i.e., based on the range of claims reasonably connected with a defendant's in-state activity or in-state impacts. ${ }^{17}$ Supreme Court decisions would refine and broaden the scope of specific jurisdiction. Correspondingly, the need would decline for expansive notions of general jurisdiction, that is, for multiple forums in which a defendant could be sued for any and all claims, related or not, to the defendant's forum contacts. Specific jurisdiction would create a sort of traveling zone of limited, controversy-based personal jurisdiction that would accompany a defendant and make it amenable to suit wherever its in-state activities or impacts caused harm, but only when plaintiffs sought to sue on sufficiently connected litigation.

When specific jurisdiction reached its maturity, general jurisdiction should, and would, be pruned-cut back, perhaps, to only states of an individual's "home" or domicile and, by analogy for corporations, to states of incorporation and principal place of business, and to other states that closely approximate the home forum. ${ }^{18}$ Two subplots undermined this narrative: The Supreme Court has failed to agree on an analysis for specific jurisdiction cases involving limited forum contacts, and it has not resolved cases involving loosely related claims. Both gaps in doctrine

15. See, e.g., Borchers, supra note 10, at 119, 129-32, 139 (noting, among other things, that "current specific jurisdiction doctrine contains several irrational elements, some of which make general jurisdiction an unpleasant necessity"); Twitchell, supra note 4, at 63739, 676 (identifying that courts were using contacts-based general jurisdiction to avoid determining the scope of specific jurisdiction and concluding that, if specific jurisdiction expanded to include all instances in which claims related to the defendant's forum contact, general jurisdiction could assume an appropriate and more "modest role"); von Mehren \& Trautman, supra note 10, at 1177-79.

16. E.g., Geoffrey C. Hazard, Jr., A General Theory of State-Court Jurisdiction, 1965 Sup. Cт. REv. 241, 274-75, 281-88; von Mehren \& Trautman, supra note 10, at 1174-79; Winton D. Woods, Pennoyer's Demise: Personal Jurisdiction after Shaffer and Kulko and a Modest Prediction Regarding World-Wide Volkswagen Corp. v. Woodson, 20 ARIz. L. REV. 861, 880-98 (1978).

17. E.g., Woods, supra note 16 , at $867,880-93$; von Mehren \& Trautman, supra note 10 , at 1147-63, 1166-76; see also Hazard, supra note 16, at 245.

18. E.g., Borchers, supra note 10, at 139 (advocating for "more rational bases of specific jurisdiction coupled with modest bases of general jurisdiction"); Brilmayer et al., supra note 10, at 742-43; Twitchell, supra note 4, at 666-70; von Mehren \& Trautman, supra note 10 , at $1174-79$. 
stem from a single source - the failure to establish a coherent theory of specific jurisdiction.

The Supreme Court's case law on specific jurisdiction has not, in fact, been expansive. The Court has narrowed specific jurisdiction by requiring that a defendant exhibit sufficient purposeful availment, i.e., sufficient purposeful direction of its conduct at a forum, in order to protect the "territorial limitations on the power of the respective States"19 and to provide clear notice to defendant that it could be subject to suit in a particular forum. ${ }^{20}$

Many lower courts, moreover, have confined specific jurisdiction in another critical way. Even when a defendant has significant forum contact, many courts require the plaintiff's claim to "arise out of," rather than more loosely "relate to" those contacts. ${ }^{21}$ The Supreme Court has avoided weighing in on this "relatedness" issue. ${ }^{22}$ Thus, many lower courts have denied specific jurisdiction when a defendant has substantial, purposeful forum contacts, but the claim is only loosely related. ${ }^{23}$ Others previously stretched "general" jurisdiction to cover these cases, concluding that the defendant's "continuous and systematic" contacts were sufficient to establish general jurisdiction and, hence, the claim need not "arise from" the defendant's forum activity. ${ }^{24}$

Professor Patrick Borchers concluded, pre-Bauman and pre-Goodyear, that such inappropriately expansive definitions of general jurisdiction were acceptable because they offset inappropriately narrow definitions of specific jurisdiction: "Given the restrictive and confused" elements of current specific jurisdiction analysis, the lower courts' broader conception of general jurisdiction supplied "an imperfect safety valve that sometimes allows plaintiffs access to a reasonable forum in cases when specific jurisdiction would deny it." 25 The Bauman Court eliminated this safety valve. ${ }^{26}$ However, Bauman also provided space for courts to construe 12.

19. Hanson v. Denckla, 357 U.S. 235, 251 (1958); see also Rhodes, supra note 5, at 409-

20. World-Wide Volkswagen Corp. v. Woodson, 444 U.S. 286, $297-98$ (1980).

21. E.g., Twitchell, supra note 4 , at $625,635-43$; von Mehren \& Trautman, supra note 10 , at $1141-44$.

22. See Helicopteros Nacionales de Colombia, S.A. v. Hall, 466 U.S. 408, 414-15 \& n.10 (1984); see also William M. Richman, Jurisdiction in Civil Actions; By Robert C. Casad, 72 CAL. L. REv. 1328, 1338-41 (1984) (book review); Twitchell, supra note 4, at 63843 \& n.144.

23. E.g., Twitchell, supra note 4, at 635-43; von Mehren \& Trautman, supra note 10, at 1141-44.

24. E.g., Borchers, supra note 10, at 139; Stein, supra note 10, at 542 (acknowledging and disparaging use of general jurisdiction "to fix inadequacies in specific jurisdiction"); Twitchell, supra note 4, at 638-43.

25. Borchers, supra note 10, at 139; accord Twitchell, supra note 4, at 652, 676; Twitchell, supra note 14, at 195-96.

26. See Daimler AG v. Bauman, 134 S. Ct. 746, 757-58 n.9 (2014) (indicating that specific jurisdiction has assumed a broader role and that general jurisdiction need no longer extend more broadly to adjust for narrow formulations of specific jurisdiction) (citing von Mehren \& Trautman, supra note 10, at 1177-79; Twitchell, supra note 4, at 676; and Borchers, supra note 10, at 139). 
specific jurisdiction more broadly and in a way that would encompass many cases in which the litigation is only loosely related to the defendant's forum contacts, but jurisdiction would nevertheless be reasonable. ${ }^{27}$

Justice Ginsburg's opinions for eight members of the Court in Bauman and for the unanimous Court in Goodyear foreshadow a broader range for specific jurisdiction. ${ }^{28}$ The Court's unanimous decision in the specific jurisdiction case of Walden $v$. Fiore also contains broader language regarding specific jurisdiction. ${ }^{29}$ Walden confirmed that due process protection of personal jurisdiction is based on protecting the individual liberty interest. ${ }^{30}$ It returned to the concepts of early post-International Shoe cases by requiring concurrent examination of the "relationship among the defendant, the forum, and the litigation" 31 -a hallmark of a reasonableness analysis. ${ }^{32}$ Inexplicably, however, the Walden Court explored the relation of the lawsuit to the forum for the sole purpose of identifying contacts of the defendant to the forum. ${ }^{33}$ The Supreme Court has, thus, used a reasonableness rationale to limit general jurisdiction and has made strides toward the reasonableness approach for specific jurisdiction, but Walden ultimately reunited the antagonistic theories of reasonableness and state territorial power to limit the reach of specific jurisdiction. ${ }^{34}$

The Court has entered a new era of constrained general jurisdiction. This era should also be characterized by broader specific jurisdiction. The Court should continue Walden's concurrent examination of the relation of the lawsuit and the defendant to the forum. It should, however, determine specific jurisdiction by using a reasonableness analysis similar to the analysis it has sometimes used in the past-one that requires a relation between the defendant and the forum, but that also considers all connections of the lawsuit to the forum in determining the breadth of specific jurisdiction as well as its outer limits. ${ }^{35}$

27. See generally Bauman at 746-62.

28. See infra notes $292-341$, and accompanying text.

29. See 134 S. Ct. 1115 (2014).

30. Id. at $1122,1125 \mathrm{n} .9$.

31. Id. at 1121 (quoting Keeton v. Hustler Magazine, Inc., 465 U.S. 770, 775 (1984) (quoting Shaffer v. Heitner, 433 U.S. 186, 204 (1977)).

32. E.g., Graham C. Lilley, Jurisdiction Over Domestic and Alien Defendants, 69 VA. L. Rev. 85, 90-91 (1983); Allen R. Kamp, Beyond Minimum Contracts: The Supreme Court's New Jurisdictional Theory, 15 GA. L. Rev. 19, 31, 33-34 (1980).

33. Walden, $134 \mathrm{~S}$. Ct. at 1124-26 (considering defendant's forum contacts, the relation of the claim to the forum, the relation of the plaintiffs to the forum and to the defendant, and the relation of the plaintiffs and defendant to the alternate forum of Georgia, but viewing all factors in light of whether they revealed forum contacts by defendant).

34. Id.

35. See infra notes 102-127 and 256-271, e.g., Kevin M. Clermont, Restating Territorial Jurisdiction and Venue for State and Federal Courts, 66 ConNell L. Rev. 411, 434, 437-38, 451-54 (1981); Robin J. Effron, Letting the Perfect Become the Enemy of the Good: The Relatedness Problem in Personal Jurisdiction, 16 Lewis \& Clark L. Rev. 867, 880, 897, 903 (2012); Heiser, supra note 10, at 923, 928-29; Lilley, supra note 32, at 113-16; Allan R. Stein, Personal Jurisdiction and the Internet: Seeing Due Process Through the Lens of Regulatory Precision, 98 Nw. U. L. REv. 411, 413, 417, 425-28 (2004); Twitchell, supra note 4, at 
In Section II, I discuss the transformation of personal jurisdiction, following International Shoe Co. v. Washington, from a jurisprudence based on state territorial authority to a doctrine of reasonableness of the forum, given the substantial connection of the litigation to the forum state. ${ }^{36}$ These cases support the specific jurisdiction analysis I ultimately advocate. I then review the Court's move, in Hanson v. Denckla and succeeding cases, away from that reasonableness approach and toward a vision of specific jurisdiction as primarily protecting against forum state encroachment on other states' jurisdictional turf. ${ }^{37}$

In Section III, I discuss the Court's recent general jurisdiction cases: Daimler AG v. Bauman ${ }^{38}$ and Goodyear Dunlop Tires Operations, S.A.v. Brown. ${ }^{39}$ These cases both narrow general jurisdiction and, in dicta, anticipate a broader scope for specific jurisdiction. Section III also analyzes Walden v. Fiore, the Court's most recent specific jurisdiction case. ${ }^{40}$ Walden provides conflicting signals. In portions of the opinion, the Court suggests a broader specific jurisdiction analysis, one based on the liberty interest and on a reasonableness analysis that examines the relation among the defendant, the forum, and the litigation, but the Walden Court applied that approach in a constrained manner. ${ }^{41}$ It considered factors relevant to a reasonableness approach, but it limited consideration to whether each factor revealed forum contacts by defendant. ${ }^{42}$

Finally, in Section IV, I conclude that the Bauman and Walden Courts correctly recognized personal jurisdiction as involving consideration of the relatedness of the defendant and the litigation to the forum state. The Court should now overtly adopt an approach similar to that sometimes used in the past and to one the Court suggests in dicta in Bauman-an analysis that considers, in a first step, whether the defendant or the episode-in-suit has at least a minimal connection with the forum. If so, in a second step, the court would consider all relevant interests, including those of the plaintiff, the defendant, and interested states, to determine if asserting jurisdiction over the particular claim at issue would be reasonable. In Section IV, I also offer some suggestions for application of that approach in a manner that will impose appropriate limits on specific jurisdiction without resort to the fiction of territorial power or its surrogates, purposeful availment and sufficiency of a defendant's forum contacts.

646, 658-59, 662-63; von Mehren \& Trautman, supra note 10, at 1166-76; Woods, supra note 16 , at $880-93$.

36. See infra notes $117-147$, and accompanying text.

37. See generally Hanson v. Denckla, 357 U.S. 235 (1958).

38. See generally Daimler AG v. Bauman, 134 S. Ct. 746 (2014). (2011).

39. See generally Goodyear Dunlop Tires Operations, S.A. v. Brown, 131 S. Ct. 2846

40. See generally Walden v. Fiore, 134 S. Ct. 1115 (2014).

41. Id. at 1120,1122 .

42. Id. 


\section{SPECIFIC JURISDICTION: EXPANSION, DECLINE, AND INDECISION}

A state court may assert personal jurisdiction if the state has authorized the court to assert jurisdiction and if the court's assertion of jurisdiction accords with due process. ${ }^{43}$ To determine whether jurisdiction satisfies the Due Process Clause, courts today examine whether the requirements of specific jurisdiction or general jurisdiction are met. ${ }^{44} \mathrm{Be}$ cause the germinal work of Professors von Mehren and Trautman identified the specific jurisdiction/general jurisdiction analysis, and because that article figures prominently in some of the Supreme Court's recent opinions and analysis, I begin with a brief discussion of that article. ${ }^{45}$ In 1966, Professors von Mehren and Trautman surveyed American case law regarding personal jurisdiction. ${ }^{46}$ They recognized two pre-existing types of personal jurisdiction that they labeled "general" and "specific" jurisdiction. ${ }^{47}$ Von Mehren and Trautman referred to jurisdiction based solely on the defendant's relationship to a forum state, without regard to the matter in controversy, as "general" jurisdiction. ${ }^{48}$ They labeled jurisdiction based on "affiliations between the forum and the underlying controversy" as "specific" jurisdiction. ${ }^{49}$ International Shoe transformed the law of personal jurisdiction, they observed, because it embraced a new analytical methodology that deemed specific jurisdiction appropriate if the case at issue bore "a reasonable and substantial connection to the forum." 50

Von Mehren and Trautman concluded that, to be consistent with the Due Process Clause, general jurisdiction ought to be narrowly construed because of its deep bite. ${ }^{51}$ When a court has general jurisdiction to adjudicate, it may assert jurisdiction over any claim, related or not, to the defendant's forum contacts. ${ }^{52}$ American courts, however, developed a broad interpretation of general jurisdiction in which (until the Court's recent

43. See Goodyear, 131 S. Ct. at 2850.

44. Federal courts have broader personal jurisdiction than state courts, which are governed by the Fifth Amendment Due Process Clause. See generally Clermont, supra note 35, at $427-28 \& \mathrm{nn} .82-85$. The limits of the federal court's broader power is rarely explored because, absent congressional legislation providing broader jurisdiction, federal courts have limited their jurisdiction to that of a court of general jurisdiction in the state in which the federal court sits. Fed. R. CIV. P. 4(k)(1)(A); see Bauman, 134 S. Ct. at 753.

45. See Daimler AG v. Bauman, 134 S. Ct. 746, 754, 762 n.20 (2014); Goodyear Dunlop Tires Operations, S.A. v. Brown, 131 S. Ct. 2846, 2851, 2857 n.5 (2011); J. McIntyre Mach., Ltd. v. Nicastro, 131 S. Ct. 2780, 2797-98, 2804 (2011) (Ginsburg, J., dissenting). Justice Thomas, who wrote the majority opinion in Walden v. Fiore, 134 S. Ct. 1115 (2014), did not reference the von Mehren and Trautman article, nor did Justice Kennedy in his plurality opinion in Nicastro, 131 S. Ct. at 2785-2791.

46. Von Mehren \& Trautman, supra note 10, at 1136.

47. $I d$.

48. $I d$.

49. Id.

50. Id. at 1147 .

51. Id. at $1143-44,1177-79$.

52. Id. at 1136. 
decisions in Bauman ${ }^{53}$ and Goodyear ${ }^{54}$ ) they permitted general jurisdiction in a corporate defendant's state of incorporation or principal place of business, and also in states in which the defendant had "continuous and systematic" contacts with the forum. ${ }^{55}$ This ultimately meant that corporations having continuous and systematic contact with most or all statesas many do-could be subjected to jurisdiction in every or almost every state on any claim, related or not, to their activity in the state.

Von Mehren and Trautman had argued against such broad jurisdiction. They concluded that general jurisdiction, which is based on a party's relation to the forum, should be limited to forums in which a party had the kind of "total, close, and continuing relations to a community implied in incorporation or in the location of a head office within a state." 56 They disparaged the tendency to construe a corporation's "continuous" contacts with a community to establish activities-based "general" jurisdiction to hear all claims against the corporation. ${ }^{57}$ Conceding that such broad notions of general jurisdiction were "understandable" when specific jurisdiction was "largely or completely unknown," they contended that in the post-International Shoe context, specific jurisdiction, rather than general jurisdiction, ought to encompass jurisdiction premised on a defendant's continuous and systematic forum contacts. ${ }^{58}$

Von Mehren and Trautman acknowledged that the courts had, by 1966, vastly increased specific jurisdiction, but they argued for continued expansion of the "more functional and less mechanical" approach of International Shoe. ${ }^{59}$ They recommended that, when specific jurisdiction matured, the courts' analysis of the relatedness issue should include "the relationship of the parties and of the controversy to the forum" and additional factors bearing on "litigational and enforcement" issues. ${ }^{60}$ In particular, they advocated for consideration of the following factors: (1) the character of the defendant's activity that led to the controversy, which included the nature of the claim at issue; (2) whether the defendant was "a corporation []whose economic activities and legal involvements were

53. Daimler AG v. Bauman, 134 S. Ct. 746 (2014).

54. Goodyear Dunlop Tires Operations, S.A. v. Brown, 131 S. Ct. 785 (2011). See also, e.g., Stein, supra note 10, at 528, 545-48 (discussing Goodyear's "apparent constriction of general jurisdiction" and suggesting a method of assessing the limits of general jurisdiction under the "essentially at home" standard).

55. E.g., Brilmayer et al., supra note 10, at 735-36, 741-723; Twitchell, supra note 14, at $182-89$.

56. Von Mehren \& Trautman, supra note 10, at 1141-44, 1177-79.

57. $I d$.

58. Id. at 1141-45, 1177-79; accord Twitchell, supra note 14, at 182-87 (noting that both the language of International Shoe and subsequent Supreme Court cases require more than "continuous and systematic" contact for general jurisdiction). The Supreme Court, in Daimler AG v. Bauman, emphasized as well that International Shoe used the terms "continuous and systematic" to describe specific jurisdiction and that general jurisdiction requires contacts that are "so 'continuous and systematic' as to render [the corporation] essentially at home in the forum." Daimler AG v. Bauman, 134 S. Ct. 746, 761 (2014) (quoting Goodyear, $131 \mathrm{~S}$. Ct. at 2851); see also id. at 761 \& nn.17-19.

59. Von Mehren \& Trautman, supra note 10, at 1164.

60. Id. at 1166 . 
pervasively multistate" or "a natural ... person whose economic activities and legal involvements were essentially local;" (3) whether the "defendant's activity foreseeably involved the risk of harm to individuals in communities other than his own"; (4) whether the plaintiff was a nonresident, or whether "[the plaintiff's] . . . affairs . . were spread out over several jurisdictions including the defendant's home;" and (5) "litigational and enforcement" issues such as the convenience of witnesses and ease of determining controlling law. ${ }^{61}$

Specific jurisdiction, however, did not experience the full extent of this anticipated growth. Instead, the Supreme Court eventually construed specific jurisdiction narrowly by requiring that a defendant must "purposefully avail itself" to the forum state before specific jurisdiction would be recognized. ${ }^{62}$ The Court did so, first, to protect "interstate federalism" concerns, concluding that even if a forum would be a reasonable place to litigate a particular controversy, "the Due Process Clause, acting as an instrument of interstate federalism, may sometimes act to divest the State of its power to render a valid judgment." 63 It later concluded that purposeful availment was necessary to give the defendant "clear notice" that it could be subject to suit in the forum. ${ }^{64}$ The "clear notice" foundation for purposeful availment has been repeatedly criticized because, among other things, a defendant's reasonable expectations must be based, in part, on Supreme Court decisions regarding the extent of specific jurisdiction. ${ }^{65}$

Lower courts also contributed to narrowing specific jurisdiction. They often require, even when the defendant has sufficiently purposeful contacts to clear the purposeful availment hurdle, that the claims at issue

61. Id. at 1164,1166-69. Other commentators have also advocated consideration of the relation of both the defendant and the lawsuit to the forum. See, e.g., Clermont, supra note 35, at 434, 437-38, 451-54; Effron, supra note 35, at 880, 897-98, 899-903; Lilley, supra note 32, at 113-16; Richman, supra note 22, at 1345; Woods, supra note 16, at 880-93; accord Lea Brilmayer and Matthew Smith, The (Theoretical) Future of Personal Jurisdiction: Issues Left Open by Goodyear Dunlop Tires v. Brown and J. McIntyre Machinery v. Nicastro, 63 S.C. L. Rev. 617, 630-33 (2012) (reminding that the Due Process Clause protects plaintiffs as well as defendants, and advocating for consideration, in appropriate cases, of the contacts of each with the forum and comparison of the burdens on defendant in defending in a distant forum with the burdens on the plaintiff in suing in a distant jurisdiction).

62. Hanson v. Denckla, 357 U.S. 235, 251-54 (1958); see also infra notes 156-180 and accompanying text.

63. World-Wide Volkswagen Corp. v. Woodson, 444 U.S. 286, 294 (1980) (citing Hanson, 357 US. at 254); see also Hanson, 357 U.S. at 250-54.

64. World-Wide, 444 U.S. at 297.

65. Id. at 312 n.18 (Brennan, J., dissenting) (noting that the Court's reasoning regarding purposeful availment and clear notice is circular because a defendant's reasonable expectations about jurisdiction must include Supreme Court decisions regarding the extent of jurisdiction); see also Borchers, The Death of the Constitutional Law of Personal Jurisdiction: From Pennoyer to Burnham and Back Again, 24 U.C. DAvis L. Rev. 19, 93-94 (1990); Brilmayer \& Smith, supra note 61, at 623; Stein, supra note 35, at 418-19; Heiser, supra note 10, at 923; Stewart Jay, "Minimum Contacts" as a Unified Theory of Personal Jurisdiction: A Reappraisal, 59 N.C. L. REv. 429, 443-44 (1981). Commentators note as well that a constitutional notice standard is inadequate if it "focuses only on the defendant's conduct and ignores other legitimate interests, such as those of the plaintiff and . . . state." Heiser, supra note 10, at 923; Jay, supra at 445-48. 
must "arise out of" the defendant's forum conduct, rather than more loosely "relate to" those contacts, thus preventing jurisdiction over claims loosely related to defendant's activity or impacts in the forum. ${ }^{66} \mathrm{The} \mathrm{Su}-$ preme Court, moreover, in Helicopteros Nacionales de Colombia, S.A. v. Hall, noted this relatedness debate, but declined to resolve it. ${ }^{67}$ Plaintiffs in Helicopteros had conceded their claims did not "arise out of" or "relate to" the defendant's forum activities and argued, instead, only based on general jurisdiction. ${ }^{68}$ The Helicopteros Court, thus, declined to reach the issue of whether "arising out of" or "related to" indicated "different connections between a cause of action and a defendant's contacts with a forum." 69 The Court has not subsequently resolved this issue.

Cases involving these "loosely" or "tenuously" related claims, ${ }^{70}$ moreover, had traits of both general and specific jurisdiction, but they were a "near miss" on the "paradigm" instances of each. ${ }^{71}$ They often missed on general jurisdiction because the defendant had substantial, often "continuous and systematic" contact with the forum, but not enough to constitute general jurisdiction. ${ }^{72}$ They also failed a paradigmatic specific jurisdiction analysis because the claims might loosely or tenuously "relate to" the forum contact or impact, but would not "arise out of" the contact. ${ }^{73}$ Examples include (1) cases in which a defendant has purposeful forum contacts but a physical injury loosely related to the contacts occurs in another forum; and (2) cases in which a defendant has continuous business contacts with a forum but never physically enters the forum. ${ }^{74}$ In a recurrent exemplar, a nonresident defendant advertises in the forum, and

66. Twitchell, supra note 4, at 638- 39 (noting that state courts extended contacts-based general jurisdiction to avoid making the difficult decisions regarding whether claims that are loosely related to defendant's forum contacts are within the scope of specific jurisdiction).

67. See Helicopteros Nacionales de Colombia, S.A. v. Hall, 466 U.S. 408 (1984).

68. Id. at $415 \&$ n.10.

69. Id.

70. Twitchell, supra note 4 , at 638-39, 648-49.

71. Richman, supra note 22, at 1337-39, 1343.

72. Richman, supra note 22 , at 1342-43. This, of course, is a pre-Daimler AG v. Bauman analysis. See Bauman, 134 S. Ct. at 754-58. After Bauman, these cases will often not constitute even a "near miss" on general jurisdiction because instances of "continuous and systematic" contacts will be analyzed primarily as cases of specific jurisdiction, which require a claim to be sufficiently connected with the defendant's forum contacts.

73. Richman, supra note 22, at 1342-43.

74. Twitchell, supra note 4, at 638 . Professor Richman accurately observed that illustrative cases cannot provide an accurate picture of the whole:

$[\mathrm{T}]$ he variations and gradations are too numerous to catalogue. For instance, some portion of the plaintiff's claim might be closely connected with the defendant's forum contacts while another portion might be unconnected. Or the plaintiff's claim might arise from activities outside the forum that breached a duty created by a relationship centered in the forum. Or the plaintiff's claim might arise from an extra-forum act of the defendant that nevertheless is part of an on-going activity that is significantly connected to the forum. It bears repetition; the variations seem endless.

Richman, supra note 22, at 1340-41 (citing the following cases, respectively, to illustrate the examples provided: Keeton v. Hustler Magazine, Inc., 465 U.S. 770 (1984); Shaffer v. Heitner, 433 U.S. 186 (1977), and Cornelison v. Chaney, 16 Cal. 3d 143 (1976)). 
a plaintiff, having responded to the advertisement, is subsequently injured in another state, but elects to sue in the plaintiff's home state. The plaintiff's case may be loosely "related to" the defendant's in-state advertising - that advertising led the plaintiff to vacation at the defendant's out-of-state hotel-but the injury at the hotel might not be construed to "arise out of" the advertising. ${ }^{75}$ In these cases, a pre-Bauman and preGoodyear court might have examined specific jurisdiction and granted or rejected jurisdiction based on the relatedness of the claim. ${ }^{76}$ Conversely it might have used general jurisdiction to avoid the "relatedness" issue, and it might have concluded that it could assert "general" jurisdiction based on the defendant's "continuous and systematic" in-state advertising. Bauman now precludes assertion of general jurisdiction.

If combined with Supreme Court and lower court decisions, Bauman could be construed to imply that the Due Process Clause permits only two limited "paradigm" categories of personal jurisdiction: (1) "specific jurisdiction," when the defendant has at least minimal contacts with a forum, the defendant has displayed sufficient purposeful availment, and the claim "arises out of" the forum contacts; 77 and (2) "general jurisdiction," which has been newly narrowed to include "a limited set of affiliations with a forum . . . 'in which the corporation is fairly regarded as at home." 78 Such an interpretation could prevent jurisdiction in many cases in which the defendant has substantial connections with or impact in a forum and jurisdiction would be both fair and reasonable, but the claim at issue is only loosely "related to" those contacts. ${ }^{79}$

75. Twitchell, supra note 4, at 638 n.130.

76. See generally Victor N. Metallo, "Arise Out of" or "Related to": Textualism and Understanding Precedent Through Interpretatio Objectificata, "Objective Interpretation"A Four Step Process to Resolve Jurisdiction Questions Utilizing the Third Circuit Test in O'Connor as a Uniform Standard, 17 Wash. \& LeE J. Civ. RTs. \& Soc. Just. 415, 426-45 (2011) (discussing the various tests used in circuit courts to determine whether claims "arise out of" or are "related to" defendant's forum contacts).

77. This would permit jurisdiction over the two exemplars of specific jurisdiction identified in International Shoe - when the defendant's activity is "continuous and systematic" and also "give[s] rise to the liabilities sued on" and when the defendant conducts activities in the state and "the obligations arise out of or are connected with the activities in the state." Int'l Shoe Co. v. Washington, 326 U.S. 310, 317, 319 (1945).

78. Bauman, 134 S. Ct. at 760 (quoting Goodyear, 131 S. Ct. at 2853-54).

79. See, e.g., Richman, supra note 22, at 1336-46 (cautioning against limiting personal jurisdiction to cases that fall within the paradigm instances of specific and general jurisdiction and suggesting that personal jurisdiction should not be viewed as constituting two or three discrete categories, but as forming a continuum model in which defendant's contacts and claim-relatedness would vary, and that, moreover, other factors would figure importantly, such as "defendant's benefits from the forum, the foreseeability of the forum litigation, lack of inconvenience, and the defendant's initiation of the relationship with the forum"); see also Rhodes, supra note 5, at 430-31 (concluding, similarly, that the narrowing of general jurisdiction after the Goodyear opinion, required that specific jurisdiction be construed more expansively, but establishing further, that the Nicastro opinions did not provide that necessary broadening of specific jurisdiction). Professors Rhodes and Robertson conclude that, after Bauman and Walden, courts should apply a two-tier specific jurisdiction analysis," one that would permit "a looser relationship" between the forum, the parties, and the case when the defendant has "continuous and systematic" forum contracts, but would require a tighter connection between the forum and the case when the "defendant's relationship with the forum is isolated or sporadic." Charles W. "Rocky" Rhodes 
I interpret the Court's decisions in Bauman and Goodyear to provide space for the Court's return to a specific jurisdiction analysis that permits jurisdiction when connections between the defendant, the controversy, and the forum state render jurisdiction reasonable. Moreover, in Walden v. Fiore, the Court suggested a type of reasonableness analysis that privileged, as in the early post-International Shoe cases, a "substantial connection" to the forum state and that emphasized the relationship to the forum of both the defendant and the litigation. ${ }^{80}$ Importantly, Walden did not limit its specific jurisdiction inquiry by asking first whether the defendant had purposefully availed and whether the claim was related to those contacts. Instead, the Walden Court considered simultaneously the following reasonableness factors: the relation of the defendant to the forum, of the plaintiff to the defendant and the forum, and of the claim to the forum. ${ }^{81}$ The Walden Court stopped short of a full reasonableness analysis, however, because it viewed each factor only to determine if it revealed contacts connecting the defendant to the forum. ${ }^{82}$

In Section II.A, I discuss International Shoe's break from the territorial power analysis of Pennoyer $v$. Neff 83 and the Court's application of a new analysis focused on the reasonableness of the forum given the controversy at issue. In Section II.B, I explore the jurisdiction-limiting approach the Court later adopted (in pursuit of protection of "interstate federalism interests") in Hanson v. Denckla and succeeding cases, as well as the Court's fluctuating conclusions regarding the policy underlying personal jurisdiction. I assume general familiarity with these cases and primarily analyze the Court's shifting conclusions regarding the policy underlying personal jurisdiction and how that debate has impacted specific jurisdiction analysis.

\section{A. Doctrinal Transformation-From Pennoyer to International Shoe}

International Shoe has been construed to mark a doctrinal shift from the state territorial power analysis of Pennoyer $v$. Neff to an analysis based on reasonableness, thus ushering in the modern era of personal jurisdiction analysis under the Due Process Clause. ${ }^{84}$ In fact, the language

and Cassandra Burke Robertson, Toward a New Equilibrium in Personal Jurisdiction, 48 U.C. Davis L. Rev. 207, 212, 235-37 \& n. 19 (2014).

80. Walden v. Fiore, 134 S. Ct. 1115, 1121-22 (2014).

81. Id. at 1122 .

82. Id. at $1124-26$

83. 95 U.S. 714 (1878)

84. Jay, supra note 65, at 429-31, 473 (recognizing that International Shoe "seemed to rest on an entirely different conceptual foundation" than Pennoyer $v$. Neff, and cataloguing articles that so suggested, but concluding that International Shoe was in fact capable of dual interpretations, one based on fairness concerns and another based on the closeness of the defendant's connection to the forum). See also Terry S. Kogan, A Neo-Federalist Tale of Personal Jurisdiction, 63 S. CAL. L. REv. 257, 257-62, 269-70, 350-58 (1990) (criticizing the view that International Shoe made a strong break with the analysis of Pennoyer $v$. Neff and concluding, instead, that International Shoe is a "paradigm-seeking" case that permits both forward-looking and backward-looking analyses). 
of International Shoe is capable of competing constructions-one that supports a reasonableness approach to personal jurisdiction and that keys on both the relation of the litigation to the chosen forum and on fairness to the litigants, and a second, narrower approach that privileges state territorial authority in a manner akin to Pennoyer $v$. Neff. ${ }^{85}$ These are the so-called "forward-looking" and "backward-looking" faces of International Shoe. 86

Under Pennoyer, personal jurisdiction was based primarily on the presence of persons or property in the forum, on consent to jurisdiction, and on domicile. ${ }^{87}$ Presence in the state triggered state court authority. ${ }^{88}$ If the defendant were present in the state at the time of service of process, the state had the power to assert in personam jurisdiction. ${ }^{89}$ If the defendant's property were present in the state, the territorial power analysis permitted assertion of in rem or quasi in rem jurisdiction in appropriate cases..$^{90}$ Pennoyer's emphasis on the physical presence of the person or property in the forum state protected both the forum state's "exclusive ... sovereignty" over persons and property in the forum and sister states' "exclusive ... sovereignty" over persons or property outside the forum. ${ }^{91}$ Thus, Pennoyer recognized and protected against a state's attempt to ex-

85. E.g., Jay, supra note 65, at 429, 473-74. Professor Jay concluded that International Shoe was capable of antagonistic interpretations and that cases after International Shoe had followed each of the differing interpretations:

The [International Shoe] opinion itself was extraordinarily ambiguous. While the controversy presented was easily resolved, the reasoning provided was capable of exploitation by two rival camps. It was possible to view the case as opening the way for a type of constitutional forum non coveniens, modified to eliminate any non-principled bias toward one party or the other. Certainly cases like McGee could be seen as endorsing this interpretation. On the other side, International Shoe might have been taken as a mandate to continue seeing the relation of the defendant to the forum as the basic concern of the due process clause. Hanson was an example of this perspective.

Jay, supra note 65, at 473. See also. Kamp supra note 32, at 31 (noting that the International Shoe standard "was subsequently subject to two different interpretations": One interpretation, like McGee v. Int'l Life Ins. Co., 355 U.S. 220 (1957), considered a number of factors, including "the regulatory concerns of the state, the convenience of the parties, the location of witnesses, the law to be applied, and the possible alternative jurisdictions." The second interpretation, in a manner similar to Hanson v. Denckla, 357 U.S. 235 (1958), required that each defendant have "physical or business connections with the state"); Kogan, supra note 84, at 257, 349-50, 353-54, 349-58 (construing International Shoe as a "paradigm-seeking" case, that permits "highly abstract alternative" constructions-one of which is a "backward-looking approach" that would accord with the "message of Pennoyer", and the other of which is a "forward-looking approach" that "focuses less on the mandate that 'contacts' must exist, ... . [and more on] fostering 'traditional notions of fair play and substantial justice'"); Glenn S. Koppel, The Functional and Dysfunctional Role of Formalism in Federalism: Shady Grove versus Nicastro, 16 Lewis \& Clark L. Rev. 905, 948-49 (2012).

86. Kogan, supra note 84 , at 350-58. See also Jay, supra note 65, at 473; Rhodes, supra note 5 , at 398-400.

87. Pennoyer v. Neff, 95 U.S. 714, 721-25, 733-36 (1877).

88. Id. at 721-25.

89. Id.

90. Id. at 721-29. See also Note, Developments in the Law: State-Court Jurisdiction, 73

Harv. L. Rev. 909, 916-18 (1960).

91. Pennoyer, 95 U.S. at 721-23. 
ert "extraterritorial jurisdiction" over people or property that would both "offend sister States and exceed the . . . limits of the [forum] State's power." 92 The territorial power analysis, however, never adequately addressed all issues of personal jurisdiction. Pennoyer, thus, immediately recognized exceptions to the requirement that either person or property be present in the forum. ${ }^{93}$ It specified that a state could determine the status of its citizens with respect to nonresident defendants, which permitted divorce actions in one spouse's absence, and it permitted states to require foreign business entities to appoint agents to be present for service of process. ${ }^{94}$

Clashing with the desire to protect the territorial authority of the states, however, was the states' growing desire to provide forums for residents to redress injury in instances in which increasingly mobile individual defendants could cause injury in the forum and leave, and corporate defendants (which increasingly carried on business in multiple forums) could cause injury through the activity of corporate agents. ${ }^{95}$ To bridge the gap between original, narrow views of corporate "presence" in a forum that underlay the in personam portion of Pennoyer's jurisdictional trilogy, courts, among other things, expanded the definitions of a corporation's implied "consent" to suit and its "presence" in the forum. ${ }^{96}$ Both eventually came to be premised on a corporation's transaction of business in the forum. ${ }^{97}$ Varied and complex case law developed regarding when a corporation's "doing business" would constitute implied consent to jurisdiction or corporate presence in the forum. ${ }^{98}$

As a counterpoint to this prevailing "doing business" analysis, Judge Learned Hand proposed, in Hutchinson v. Chase \& Gilbert, Inc., 99 a "reasonableness" analysis that would balance the inconvenience to the defendant with fairness to the plaintiff. ${ }^{100}$ In Hutchinson, a forerunner to

92. Bauman v. Daimler AG, 134 S. Ct. 746, 753 (2014) (quoting Shaffer v. Heitner, 433 U.S. 186, 197 (1977)). Pennoyer's territorial analysis never fully explained personal jurisdiction. Indeed, the Pennoyer Court hastened to catalogue exceptions that would permit a reasonable doctrine of personal jurisdiction, including voluntary appearance of the defendant; status of a state resident, which would permit divorce actions in one spouse's absence; and a business entity's appointment of an agent for service of process. See, e.g., Luther L. McDougal III, Judicial Jurisdiction: From a Contacts to an Interest Analysis, 35 VAnD. L. Rev. 1, 1-2 \& n.5 (1982). The Court quickly supplemented these exceptions with the fictions of "implied consent" and "presence" based on doing business in the state. Id.

93. Pennoyer, 95 U.S. at 735-36.

94. Id. at 721-25, 734; Philip B. Kurland, The Supreme Court, the Due Process Clause and the In Personam Jurisdiction of State Courts-From Pennoyer to Denckla: A Review, 25 U. CHI. L. Rev. 569, $572-73$ (1958); Hazard, supra note 16, at 271.

95. E.g., Kamp, supra note 32, at 31-35; McDougal, supra note 92, at 2; Note, supra note 90 , at $917-18$

96. E.g., Clermont, supra note 35, at 414-16; Kurland, supra note 94, at 575-86; Note, supra note 90 , at $920-23$.

97. Kurland, supra note 94 , at 584; Note, supra note 90 , at 920.

98. Kurland, supra note 94, at 584-85; Note, supra note 90, at 922-23.

99. 45 F.2d 139, 141 (2d Cir. 1930).

100. Hutchinson 45 F.2d at 141-42. 
International Shoe's "reasonableness" analysis, ${ }^{101}$ Judge Hand also contended that the fiction of corporate "presence" based on doing business in the forum should be abandoned in favor of a standard that "puts the real question"- "whether the extent and continuity of what [the corporation] has done in the state in question makes it reasonable to bring it before one of its courts." 102

International Shoe, likewise, espoused a reasonableness analysis, holding that to subject a nonresident defendant to in personam jurisdiction, due process required only that the defendant have "certain minimum contacts" with the state, "such that the maintenance of the suit does not offend 'traditional notions of fair play and substantial justice.'"103 International Shoe, however, presents two faces-one forward-looking face, based on language that speaks in terms of reasonableness or fairness of the forum based on the litigation at issue, and a second, backward-looking face that privileges Pennoyer's premise that state territorial authority must be respected. ${ }^{104}$ In line with the forward-looking approach, the International Shoe Court rejected analysis based on a corporation's fictitious "presence" in the forum, emphasizing that the inquiry was a symbolic one that, in fact, required courts to determine whether in-state acts of the corporate agent were "sufficient to satisfy the demands of due process." 105 To determine whether those demands were met, International Shoe continued, required analysis of whether the corporation's "contacts ... with the state [rendered it] reasonable, in the context of our federal system of government, to require the corporation to defend the particular suit which is brought there." ${ }^{106}$ Among the relevant considerations, the Court noted, was "[a]n 'estimate of the inconveniences' . . . to the corporation from a trial away from its 'home' or principal place of business." 107

International Shoe instructed also that jurisdictional decisions would vary based on the extent and nature of the defendant's contacts with the forum and the relatedness of the litigation. ${ }^{108}$ The Court, thus, provided several circumstances in which the jurisdictional decision might diverge based on variations in the nature and extent of the defendant's forum contacts and the relatedness of the litigation, including instances of "single or isolated" contacts, "continuous and systematic" contacts, and "substantial" contacts. ${ }^{109}$ These instances can be construed as looking

101. Int'l Shoe Co. v. Washington, 326 U.S. 310, 316-17 (1945) (citing Hutchinson, 45 F.2d at 139, 141); Shaffer v. Heitner, 433 U.S. 186, 203-04 (1977) (citing Hutchinson, 45 F2d. at 141). See also Note, supra note 90, at 923.

102. Hutchinson, 45 F.2d at 141.

103. Int'l Shoe, 326 U.S. at 316 (quoting Milliken v. Meyer, 311 U.S. 457, 463 (1940)). See also Kurland, supra note 94, at 589.

104. See supra notes 84- 86 and accompanying text.

105. Int'l Shoe, 326 U.S. at 316-17.

106. Id.

107. $I d$.

108. Id. at 317-318.

109. Those illustrations are as follows: (1) there would be jurisdiction if corporate activity in a forum is not only "continuous and systematic, but also give[s] rise to the liabilities 
backward toward Pennoyer's protection of state territorial boundaries. International Shoe emphasized, however, that the analysis was not to be "mechanical or quantitative ... a little more or a little less." 110 Instead, it should "depend ... upon the quality and nature of the activity in relation to the fair and orderly administration of the laws." 111 In Shaffer v. Heitner, the Court later summarized the analysis as requiring that a court examine the "relationship among the defendant, the forum, and the litigation, rather than the mutually exclusive sovereignty of the States on which the rules of Pennoyer rest[ed]."112 But, again, the Shaffer opinion was ambiguous. Shaffer included expansive statements of the scope of personal jurisdiction, but it ultimately applied the language narrowly. ${ }^{113}$

International Shoe's forward-looking approach suggested doctrinal change from Pennoyer's protection of state territorial authority to an analysis privileging reasonableness under the circumstances. This framework, which the Court used in cases immediately following International Shoe, was necessarily accompanied by a change in underlying policy. Whereas Pennoyer's analysis was premised on safeguarding interstate federalism interests, International Shoe's reasonableness assessment protected the individual liberty interest.

\section{B. Applying the Reasonableness Approach- International Shoe to MCGeE}

In its immediate post-International Shoe cases, the Supreme Court analyzed specific jurisdiction using a reasonableness analysis. In three cases, the Court based its analysis on the connectedness of the lawsuit to the forum and, hence, whether it was fair to the parties to litigate in the chosen forum. ${ }^{114}$ One can extract from these cases (as von Mehren and Trautman did) the functional considerations that von Mehren and Trautman deemed critical to development of a "mature" specific jurisdiction analysis regarding relatedness of the defendant and litigation to the fo-

sued on," $i d$. at 317 ; (2) there would not be jurisdiction based on the corporate agent's "single or isolated" acts when the suit is on "causes of action unconnected with the activities there;" however, in other instances, "single or occasional" acts "because of their nature and quality and the circumstances of their commission [might] be deemed sufficient to render the corporation liable to suit," $i d$. at 317-18; (3) some "continuous corporate operations within a state [might be] ... so substantial and of such a nature as to justify suit against it on causes of action arising from dealings entirely distinct from those activities," $i d$. at 318; and (4) if the defendant had "no contacts, ties, or relations" with the state, there would be no jurisdiction. Id. at 319 .

110. Id. at 319 .

111. Id., 319.

112. Shaffer v. Heitner, 433 U.S. 186, 204 (1977).

113. See, e.g., Jay, supra note 65, at 466 (noting that the Shaffer Court purported to decide the case on the basis of a "fairness" inquiry, but ultimately defaulted to a "minimum contacts approach" that "curtail[ed] discussion in favor of a dogmatic deference to defendants").

114. Travelers Health Ass'n v. Virginia, 339 U.S. 643 (1950); Mullane v. Ctr. Hanover Bank \& Trust Co., 339 U.S. 306 (1950); McGee, 355 U.S. 220 (1957). 
rum ${ }^{115}$ - one that would ultimately permit the limitation of general jurisdiction to a corporation's state of incorporation and principal place of business. ${ }^{116}$

The reasonableness inquiry of the early post-International Shoe cases included assessment of the following factors: (1) the claim, ${ }^{117}$ the dollar amount at issue, and the extent and nature of the defendant's and plaintiff's forum connections; (2) whether "economic activities" of the defendant were at issue;118 (3) whether the defendant was a corporation or individual, whether the defendant's "economic activities and legal involvements were pervasively multistate," and whether the "defendant's activity foreseeably involved the risk of serious harm to individuals in [other] communities"; 119 (4) whether the plaintiff acted in a multistate or local manner; ${ }^{120}(5)$ the comparative ease with which the defendant could litigate in the forum and the plaintiff could litigate in the defendant's home state or other alternative forum; ${ }^{121}(6)$ the interests of the states at issue; and (7) issues regarding efficient conduct of litigation. ${ }^{122}$

Combined, these factors indicated whether the litigation was sufficiently connected with the forum to permit specific jurisdiction. They also permitted a court to tailor the reasonableness of jurisdiction to the facts, ensuring that the small, local defendant (for whom the Court expresses continuing and appropriate concern) as well as the local plaintiff with a small claim may each be treated fairly. Although it is difficult to create a one-size-fits-all rule for all issues of personal jurisdiction, courts may, from these considerations, fashion reasonable or fair outcomes for varying scenarios. ${ }^{123}$ The analysis would broaden specific jurisdiction in some

115. Von Mehren \& Trautman, supra note 10, at 1166-69 (relying on McGee v. Int'l Life Ins. Co., 355 U.S. 220 (1957), Hess v. Pawloski, 79 U.S. 274 (1927), and on an article discussing the "phenomenon of an insurance company conducting a defense in a case such as Hess v. Pawloski").

116. Von Mehren \& Trautman, supra note 10, at 1179.

117. The McGee Court deemed it significant that the claim at issue was a small-dollar claim by an insured against a nonresident insurer that refused to pay on a claim. McGee, 355 U.S. at 223. Travelers keyed on the state's "interest in all insurance policies protecting its residents," Travelers Health Ass'n v. Virginia, 339 U.S. 643, 647 (1950); and the Mullane Court deemed it critical that the claim was for an accounting "to close trusts that exist by the grace of [New York] laws and are administered under . . . its courts." Mullane, 339 U.S. at 313.

118. McGee, 335 U.S. at 223; Travelers, 339 U.S. at 645-46.

119. McGee, 355 U.S. at 223-24; Travelers, 339 U.S. at 646-47. See also Von Mehren \& Trautman, supra note 10 , at 1167-1168.

120. Von Mehren \& Trautman, supra note 10, at 1167-1168.

121. McGee, 355 U.S. at 223-24; Mullane, 339 U.S. at 313; Travelers, 339 U.S. at 648-49.

122. McGee, 355 U.S. at 223; Travelers, 339 U.S. at 648-49. See also Von Mehren \& Trautman, supra note 10, at 1167-69.

123. Courts were, in fact, in the process of developing such reasonable outcomes before the Supreme Court turned from this analysis in Hanson v. Denckla. See Note, supra note 90, at 925 (noting that, notwithstanding the variability of a reasonableness standard, courts had, post-International Shoe, identified "recurring situations" in which foreign corporations would be subject to jurisdiction); accord Hazard, supra note 16, at 283 (suggesting that the perceived vagueness of the reasonableness approach could be resolved by "arbitrary particularization," which is exemplified by creation of classes of cases where jurisdiction is appropriate under long-arm statutes). 
instances. The increase is warranted, however, in a world in which interstate travel and communication have become the rule, interstate economic activity is the norm, and general jurisdiction has been narrowed.

In the first case, Travelers Health Ass'n v. Virginia, defendant Travelers, a Nebraska corporation, had entered into numerous insurance contracts in Virginia without opening an office in the state or sending agents into the state. ${ }^{124}$ Travelers typically obtained new Virginia members, instead, through unpaid recommendations of existing Virginia members. ${ }^{125}$ These recommendations resulted in Travelers' insurance certificates being "systematically and widely delivered in Virginia." 126 Because it had no office or agents in Virginia, Travelers declined to comply with Virginia Blue Sky laws requiring registration of companies that sold insurance certificates in the state. ${ }^{127}$ When Virginia initiated a cease and desist action regarding Travelers' failure to register, Travelers argued lack of personal jurisdiction. ${ }^{128}$

In a 5-4 decision, the Travelers Court held that the Due Process Clause permitted personal jurisdiction. ${ }^{129}$ In so concluding, the Court examined the nature of claim, the defendant's conduct and interest, the state's interests, the insureds' interests, and various litigation-related factors. ${ }^{130}$ The Court emphasized that the defendant had reached into the state of Virginia, admittedly without sending agents, and had "create[d] continuing relationships" with numerous residents over a period of years. ${ }^{131}$ Moreover, the Court recognized a strong regulatory interest of the state in insurance policies protecting its citizens and a strong interest of the state in providing a forum for redress of injury, particularly since the claims at issue would typically be too small to warrant the expense of suit in defendant's distant state of incorporation. ${ }^{132}$ Finally, the Court observed that relevant witnesses and the claim investigation would most likely be in Virginia. ${ }^{133}$

Thus, the Travelers Court noted a connection of the defendant and the litigation to the state and, correspondingly, a strong interest of the state in providing a forum for the suit. ${ }^{134}$ The Court also concluded that a comparative defendant-insured assessment favored requiring the defendant to litigate in the chosen forum: The defendant had acted, in a multi-state manner, to cultivate a pervasive and continuous presence that benefitted

124. Travelers, 339 U.S. at 645-46.

125. Id. at 646 .

126. Id. at 646,648 .

127. Id. at 646-47.

128. Id.

129. Id. at 647-49. See Kurland, supra note 94, at 593 (concluding that Travelers revealed a "thoroughly divided court" and that "[t]he vote on the merits was ... five to four, with one of the five feeling it necessary to file an opinion of his own").

130. Travelers, 339 U.S. at 645-49.

131. Id. at 647 .

132. Id. at $647-49$.

133. Id. at 649 .

134. Id. at 648 . 
the defendant economically and that would from time to time result in litigation, while the insureds had acted in a local manner and would typically pursue claims too small to warrant litigation in defendant's home state. ${ }^{135}$ Issues of efficient litigation also warranted suit in the state. ${ }^{136}$ The Travelers case parallels some contemporary cases of "loosely related" forum contacts in which the defendant creates a strong forum presence without entering the state or having agents in the state.

In a second case, Mullane v. Cent. Hanover Bank \& Trust Co., the Court similarly balanced relevant interests of the state, defendant, and plaintiff to determine the reasonableness of asserting personal jurisdiction. ${ }^{137}$ Mullane examined whether a New York court could, in a suit to settle the accounts of a common trust fund established in New York, exert jurisdiction over numerous nonresident defendants who were individual beneficiaries of the trust. ${ }^{138}$ With little factual analysis, the Court balanced the interests of the state, the plaintiff-trust company, the non-resident, and defendant beneficiaries and held that the Due Process Clause permitted jurisdiction:

It is sufficient to observe that ... the interest of each state in providing means to close trusts that exist by the grace of its laws and are administered under the supervision of its courts is so insistent and rooted in custom as to establish beyond doubt the right of its courts to determine the interests of all claimants, resident or nonresident, provided its procedure accords full opportunity to appear and be heard."139

Finally, in McGee v. Int'l Life Insurance Co., the Supreme Court determined in a unanimous decision that due process would permit suit against a defendant that had only a single contact with the state-one that created a "substantial connection" with the state. ${ }^{140}$ The Court did so without creating categorical rules for "isolated" contact, but it did assess the defendant's single forum contact in light of other factors regarding the relatedness of the litigation, or "episode-in-suit," to the forum state. ${ }^{141}$ In $M c G e e$, defendant International Life had issued a single reinsurance certificate to a California insured, which the insured accepted. ${ }^{142}$ Following the insured's death, his mother, Lulu B. McGee, obtained a judgment in California requiring International Life to pay the proceeds of the policy to her as the beneficiary. ${ }^{143}$ When Mrs. McGee attempted to enforce the

\footnotetext{
135. Id. at $648-49$.

136. Id. at 649 .

137. Mullane v. Ctr. Hanover Bank \& Trust, 339 U.S. 306 (1950). Clermont, supra note 35, at 416-17 (noting that the Mullane analysis is consistent with a fairness approach).

138. Mullane, 339 U.S. at 309-11.

139. Id. at 313.

140. McGee, 355 U.S. at 223.

141. See generally. Id. at 223-24.

142. Id. at 221-22. The California insured originally purchased the life insurance from Empire Mutual Insurance Company. International Life later assumed Empire Mutual's insurance obligations. Id. at 221.

143. Id. at 221.
} 
judgment in Texas, however, International Life objected to the California court's authority to enter judgment against it. ${ }^{144}$

The McGee Court upheld jurisdiction, considering it important that the suit was "based on a contract which had a substantial connection with" California, including that the contract was delivered in the state, the insured paid the premiums from California, and the insured lived in California until he died. ${ }^{145}$ In so deciding, the Court considered: (1) the substantial connection of the insurance contract to the forum; (2) the "manifest interest" of the state in providing effective redress when insurance companies refuse to pay claims; (3) a comparison of defendant's ability to litigate in the chosen forum and plaintiff's ability to litigate a small-dollar claim in the defendant's distant home; and (4) the crucial witnesses that would be located in the insured's state. ${ }^{146}$ In light of these factors, the Court concluded, that any inconvenience to the defendant would not approach a denial of due process. ${ }^{147}$

In these cases, the Court's contextual analysis of the relation of the controversy to the forum included assessment of the defendants' contacts with the state, the type of claim at issue, the relation of the plaintiff to the forum, the states' interests, whether the plaintiff or defendant were individuals or corporations, whether either acted in an interstate manner while the other acted locally, and whether either acted for economic gain, as well as litigation considerations. These inquiries "put[] the real question" of whether it was reasonable, in the context of the lawsuit at issue, to require the defendant to litigate in the chosen forum. ${ }^{148}$ The inquiries both expanded the scope of specific jurisdiction (jurisdiction was available in $M c G e e$ based on defendant's single forum contact) ${ }^{149}$ and established the boundaries of specific jurisdiction based on the connectedness of the litigation, the defendant, and the plaintiff to the forum. Jurisdiction would not, for instance, be available under the Court's analysis had the $M c G e e$ plaintiff moved to Oregon or Indiana and attempted to sue in her new state of residence. ${ }^{150}$ Certainly, in such a scenario, the plaintiff would

\footnotetext{
144. Id.

145. Id. at 223 .

146. Id. at $123-24$.

147. Id. at 224. These are among the factors that Justice Ginsburg deemed important in her dissenting opinion in J. McIntyre Mach., Ltd. V. Nicastro, 131 S. Ct. 2780, 2794-97, 2800-04 (2011) (Ginsburg, J., dissenting), and she suggested, in Daimler AG v. Bauman, 134 S. Ct. 746 (2014), would be important to the specific jurisdiction inquiry (citing Travelers Health Ass'n v. Virginia, 339 U.S. 643 (1950)).

148. See Kurland, supra note 94, at 584.

149. Id. at 223-24.

150. See Keeton v. Hustler Magazine, Inc., 465 U.S. 770, $775-77$ (1984) (permitting jurisdiction in a forum in which plaintiff was a nonresident, but based on additional factors including the defendant's limited, but regular, business in the forum, multiple state interests, and litigation efficiency). See also Kurland, supra note 94, at 591 (recognizing that a state of domicile is often "vitally interested in obtaining justice for its inhabitants," but asserting that use of plaintiff's domicile or residence alone as a basis for personal jurisdiction "would indeed be a startling innovation in Anglo-American jurisprudence," and suggesting that the factor probably must be combined with others to permit jurisdiction) (quoting Dodd, Jurisdiction in Personal Actions, 23 ILl. L. Rev. 427, 437 (1929)); Jay,
} 
have a relation with the Oregon or Indiana forum and she would possess the plaintiff's ever-present desire to sue in her home forum. However, the defendant would have no contact there, the contract would be unrelated to the forum, California's regulatory interests would not accompany the plaintiff, and the litigation considerations regarding available witnesses would not favor the forum.

In the wake of the McGee decision, some commentators contended that the reasonableness analysis of International Shoe was ambiguous and amorphous and would not impose sufficient limits on specific jurisdiction. ${ }^{151}$ Others considered that the reasonableness analysis provided too little protection for state territorial boundaries and interstate federalism and thus, argued for giving primacy to the so-called "backward-looking face" of International Shoe. ${ }^{152}$ Interestingly, the "amorphous" reasonableness analysis would be replaced not with the certainty of the in personam/in-rem/quasi in rem analysis of Pennoyer $v$. Neff, ${ }^{153}$ but with an equally amorphous analysis of quantity of contacts and sufficiency of "purposeful availment."154

\section{Reconsidering the Modern Analysis-Hanson v. Denckla to the Present}

Just one year after its unanimous decision in McGee and a scant thirteen years after the International Shoe decision, however, a divided Court reversed course and returned to an analysis that privileged "interstate federalism" interests and protection of state territorial limits, i.e., the so-

supra note 65 , at 463-64 (accepting that there may be no jurisdiction in a forum with no relation to the defendant other than that the plaintiff chose to sue there, but suggesting that usually the defendant does have some additional relation, though that may simply be that the plaintiff's move was foreseeable to the defendant, and, in such instances, the Court should explain why there is no jurisdiction); but see McDougal, supra note 92, at 8-10,1314, 26-31 (advocating an analysis that would permit jurisdiction based on a state's interest, including the interest in providing a forum for residents to bring suit, subject to defendant's showing that the forum would impose an undue burden); Kogan, supra note 84, at 367-71 (presenting a "mutual inconvenience" paradigm for personal jurisdiction that accords little importance to state boundaries or sovereignty).

151. E.g., Ehrenzweig, supra note 5, at 290-91; Hazard, supra note 16, at 283 (acknowledging that a perceived "defect" of the reasonableness analysis was "vagueness ... [that could] make jurisdictional litigation uncertain at the trial level and frequent at the appellate level" but concluding that there would be recurring similar situations).

152. See Kamp, supra note 32, at 37-39; see also Kurland, supra note 94, at 569, 621-22.

153. 95 U.S. 714 (1877). And even that "certainty" is suspect, as courts, in the preInternational Shoe era, found it necessary to create "[a] considerable body of case law ... setting forth many technical distinctions as to what constituted doing business" and, hence, 'presence' or 'implied consent' of a corporation to jurisdiction." Note, supra note 90, at 922. See also supra note 92.

154. E.g., Clermont, supra note 35, at 446; Jay, supra note 65, at 463-64; Kamp, supra note 32 , at 44-45, 53 (observing that it is "impossible to answer in definite terms" what minimal number of contacts is required; that the Court has created a "mathematical morass;" and that the "Court's analysis leads to greater uncertainty"). The Court's decision in Walden v. Fiore reflects the ambiguity of a "sufficiency of contacts" approach, as the Court considered factors that might tie the controversy to the forum but ultimately concluded, with no explanation for its decision, that the defendant had no meaningful contacts with the state. Walden v. Fiore, 134 S. Ct. 1115, 1124-26 (2014). 
called "backward-looking face" of International Shoe. ${ }^{155}$ The Court ultimately protected interstate federalism interests by requiring a narrowly focused inquiry into the defendant's purposeful availment and the sufficiency of defendant's forum contacts. ${ }^{156}$

In Hanson v. Denckla, the Court concluded that personal jurisdiction protects both liberty interests and state territorial interests. ${ }^{157}$ One of the interests had to take precedence, however, and the Hanson Court elevated protection of interstate federalism interests. ${ }^{158}$ In a display of perhaps unparalleled indecision (or disagreement), the Court has reversed course on this issue multiple times. ${ }^{159}$ Moreover, the decision on underlying policy matters. To protect against forum state intrusion on the interests of sister states, Hanson introduced a one-dimensional requirement that a defendant must "purposefully avail[ ] itself of the privilege of conducting activities within the forum State, thus invoking the benefits and protections of its laws." 160 It also concluded that the "unilateral activity of those who claim some relationship with a non-resident defendant cannot satisfy the requirement of contact with the forum," 161 thus minimizing the importance of a plaintiff or other person's connection to or interest in a forum. ${ }^{162}$ Purposeful availment alone, however, is not an accurate measure of a defendant's connection to or impact in a forum, and it is not functionally tied to any articulated interest of the forum state or other states. As used by the Court, purposeful availment also reintroduced the "power" analysis of Pennoyer, providing a first-step inquiry that often precludes specific jurisdiction based on a state's lack of "power" over the defendant before a court may even reach the secondstep reasonableness analysis of the early post-International Shoe cases. ${ }^{163}$

155. See supra notes 84-86, and accompanying text.

156. Some scholars have concluded that purposeful forum contacts can be viewed as the new "presence" in the forum, but that purposeful forum contacts is insufficiently tied to values that personal jurisdiction ought to protect. E.g., Clermont, supra note 35, at 445-47; Jay, supra note 65, at 474-75; Kogan, supra note 84, at 351-53; Lilley, supra note 32, at 93, 108.

157. Hanson stated as follows:

[R] estrictions [on the personal jurisdiction of state courts] are more than a guarantee of immunity from inconvenient or distant litigation. They are a consequence of territorial limitations on the power of the respective States. However minimal the burden of defending in a foreign tribunal, a defendant may not be called upon to do so unless he has had the 'minimal contacts' with that State that are a prerequisite to its exercise of power over him.

Hanson v. Denckla, 357 U.S. 235, 251, 255 (1958)

158. See generally, id. at 251-54.

159. See infra notes $160-214$, and accompanying text.

160. Hanson, 357 U.S. at 253.

161. Id.

162. E.g., Rhodes, supra note 5, at 402-04.

163. E.g., Burger King Corp. v. Rudzewicz, 471 U.S. 462, 477-78 (1985); World-Wide Volkswagen Corp. v. Woodson, 444 U.S. 286, $292-94$ (1980). See also Hanson, 357 U.S. at 251-52 (failing to find purposeful availment, and, thus, concluding the analysis with a finding of no minimum contacts by the defendant at issue). Accord Jay, supra note 65, at 47475; Kamp, supra note 32, at 20-21, 29, 39-44; Rhodes, supra note 5, at 406. 
The Hanson Court assessed Florida's authority to assert in personam jurisdiction over a Delaware trust company that sent trust income to and "carried on several bits of trust administration" with Florida domiciliary, Dora Browning Donner. ${ }^{164}$ Mrs. Donner had created the trust while living in Pennsylvania and had named the Delaware trust company as trustee. ${ }^{165}$ She later moved to Florida. ${ }^{166}$ In a 5-4 decision, the Court held that jurisdiction over the trust in Florida state court was not consonant with due process because the trust had not "purposefully avail[ed] itself of the privilege of conducting activities within the forum State, thus invoking the benefits and privileges of its laws." 167 Unilateral action by the Florida settlor would not satisfy the requirement of minimum contacts by the trust. ${ }^{168}$ Absent purposeful, forum-directed action, the defendant trust company could have no "contact" with Florida, and thus lacked the "minimum contacts" essential to personal jurisdiction. ${ }^{169}$

The Hanson decision initiated two changes that restricted a court's authority to assert personal jurisdiction. First, Hanson emphasized that the Due Process Clause serves interstate federalism interests as well as liberty interests, and it imposed "territorial limitations" on the power of states, even if asserting jurisdiction would be entirely fair to the defendant. ${ }^{170}$ If a defendant did not purposefully avail itself to the forum, thus receiving the benefits and privileges of forum law, it had no contacts with the forum that a court could recognize. ${ }^{171}$ Absent minimum contacts, no analysis of other connections of the litigation to the state was warranted. ${ }^{172}$ Thus, the reasonableness analysis of International Shoe's forward-looking construction bowed to interstate federalism interests.

Second, through the purposeful availment requirement, ${ }^{173}$ Hanson elevated the importance of the quantum of the defendant's forum contacts, and it redefined the type of contact necessary to establish "minimum con-

164. Hanson, 357 U.S. at 238-40, 246, 250 (1958). The Court also held that there was no basis for in rem jurisdiction. Id. at 246-59.

165. Id. at 238-39.

166. Id.

167. Id. at 251-53 (citing Int'l Shoe Co. v. Washington, 326 U.S. 310, 319 (1945), but failing to acknowledge that International Shoe anticipated that, in the absence of "contacts," the broader "ties[] or relations" with the forum state could suffice).

168. Id. at 253 .

169. Id. at 253-54.

170. Id. at 251, providing as follows:

[I]t is a mistake to assume that [the] trend [to a more flexible analysis of personal jurisdiction under International Shoe] heralds the eventual demise of all restrictions on the personal jurisdiction of state courts . . . Those restrictions are more than a guarantee of immunity from inconvenient or distant litigation. They are a consequence of territorial limitation on the power of the respective States. However minimal the burden of defending in a foreign tribunal, a defendant may not be called upon to do so unless he has had the 'minimal contacts' with that State that are a prerequisite to its exercise of power over him.

Id. (emphasis added) (citations omitted).

171. Id. at 253-54.

172. See id. at 254 .

173. See id. at 253-54. 
tacts." After Hanson, the Court's cases take on much more of the quantitative, mechanical, "a little more or a little less" analysis disparaged in International Shoe. ${ }^{174}$ Hanson seemed to render a defendant's purposeful availment a prerequisite to jurisdiction and to devalue consideration of the relation of the lawsuit to the forum, and hence, the interests of various states, the plaintiff, and other litigation considerations. ${ }^{175}$ Subsequent cases confirmed this. ${ }^{176}$ The Court ultimately acknowledged that the "reasonableness" factors constituted part of the due process inquiry. ${ }^{177}$ Those factors included factors considered important in the court's early post-International Shoe cases-the forum state's interest, the plaintiff's interest in convenient and effective relief, the interstate judicial system's interest in efficient resolution of cases, and shared state interests in "furthering fundamental substantive social policies." 178 Though the precise relation of the purposeful availment/minimum contacts analysis to the "reasonableness" or "fairness" factors remains ambiguous, ${ }^{179}$ the Court has employed a two-part minimum contacts and reasonableness analysis, in which purposeful availment and minimum contacts are generally a prerequisite to reaching the reasonableness analysis. ${ }^{180}$

Since Hanson, the Court has continued to debate whether the Due Process Clause protects individual liberty interests, interstate federalism interests, or both, and, correspondingly, to revisit the relation of the purposeful availment/minimum contacts analysis to the "reasonableness" or "fairness" factors. In its 1980 decision in World-Wide Volkswagen v. Woodson, a divided Supreme Court confirmed that the due process re-

174. Int'l Shoe Co. v. Washington, 326 U.S. 310, 319 (1945).

175. See Hanson, 357 U.S. at 253.

176. E.g., Asahi Metal Indus. Co. v. Superior Court, 480 U.S. 102, 113 (1987); Burger King Corp. v. Rudzewicz, 471 U.S. 462, 475-79 (1985); World-Wide Volkswagen Corp. v. Woodson, 444 U.S. 286, 292-94 (1980).

177. World-Wide, 444 U.S. at 292.

178. See infra notes 386-87, and accompanying text.

179. Walter W. Heiser, Toward Reasonable Limitations on the Exercise of General Jurisdiction, 41 SAN Diego L. REv. 1035, 1040-42 (2004) (referring to the following factors as central in determining whether "personal jurisdiction is 'reasonable", and part of as the "reasonableness inquiry": "the burden on the defendant, the interests of the forum State, ... the plaintiff's interest in obtaining relief . . . the interstate judicial system's interest in obtaining the most efficient resolution of controversies[,] and the shared interests of the several States in furthering fundamental substantive social policies") (internal quoting omitted); Woods, supra note 16, at 890 (referring to similar factors "fairness factors"). Professor Kamp acknowledged that the "factors" are primarily drawn from prior Supreme Court cases. Kamp, supra note 32, at 39-40, 43.

180. E.g., Burger King, 471 U.S. at 477-78; World-Wide, 444 U.S. at 291-92. But see Asahi Metal Indus. Co., 480 U.S. at 111-112, 116 (O'Connor, J.) (including portions of an opinion written for a plurality and portions written for the Court), and id. at 116-22 (Brennan, J., concurring in part and concurring in judgment) (disagreeing on the purposeful availment/minimum contacts analysis, but reaching the fairness analysis and concluding that jurisdiction would not be reasonable on the facts at issue). Daimler AG v. Bauman, however, in dicta, proposes a modified two-part test in which the first step would be to assess "whether the connection between the forum and the episode-in-suit could justify ... jurisdiction." Daimler AG v. Bauman, 134 S. Ct. 746, 762 n.20 (2014). Walden v. Fiore also minimizes "purposeful availment," but focuses on a threshold requirement of minimum contacts by defendant. Walden v. Fiore, 134 S. Ct. 1115, 1122 (2014). 
quirement of "minimum contacts" both protected a liberty interest and ensured that states would not assert jurisdiction "beyond the limits imposed on them by their status as coequal sovereigns in a federal system." 181 The World-Wide Court analyzed whether a New York retailer and its regional distributor could be required to submit to jurisdiction in Oklahoma regarding an accident in Oklahoma, but involving a vehicle sold to plaintiff in New York. ${ }^{182}$ Neither the dealer nor the distributor sold cars in Oklahoma. ${ }^{183}$ The Court again privileged protection of interstate federalism interests. ${ }^{184}$ It found no purposeful availment and, thus, concluded that defendants had "no contacts, ties, or relations" with the forum. ${ }^{185}$ The lack of contacts precluded further analysis, but the Court explained that, in appropriate cases, a court would also consider the reasonableness factors, including those relating to the interests of the state and the plaintiff. ${ }^{186}$

Two years later, in Insurance Corp. of Ireland, Ltd. v. Compagnie Des Bauxites de Guinee, the Court again reconsidered.187 It concluded that personal jurisdiction protects only "an individual liberty interest." 188 It "restrict[s] . . . judicial power not as a matter of sovereignty, but as a matter of individual liberty." 189 The Court also concluded that the Due Process Clause is "the only source of the personal jurisdiction requirement and the Clause itself makes no mention of federalism concerns," 190 but the Court thereafter preserved a federalism focus, concluding that the restriction on state sovereign power is "ultimately a function of the liberty interest." 191 Still later, in Asahi Metal Industry Co. v. Superior Court ${ }^{192}$ the justices failed to muster a majority on the issue of whether the forum-directed conduct of a foreign manufacturer of component parts, in a stream of commerce case, was sufficient to constitute pur-

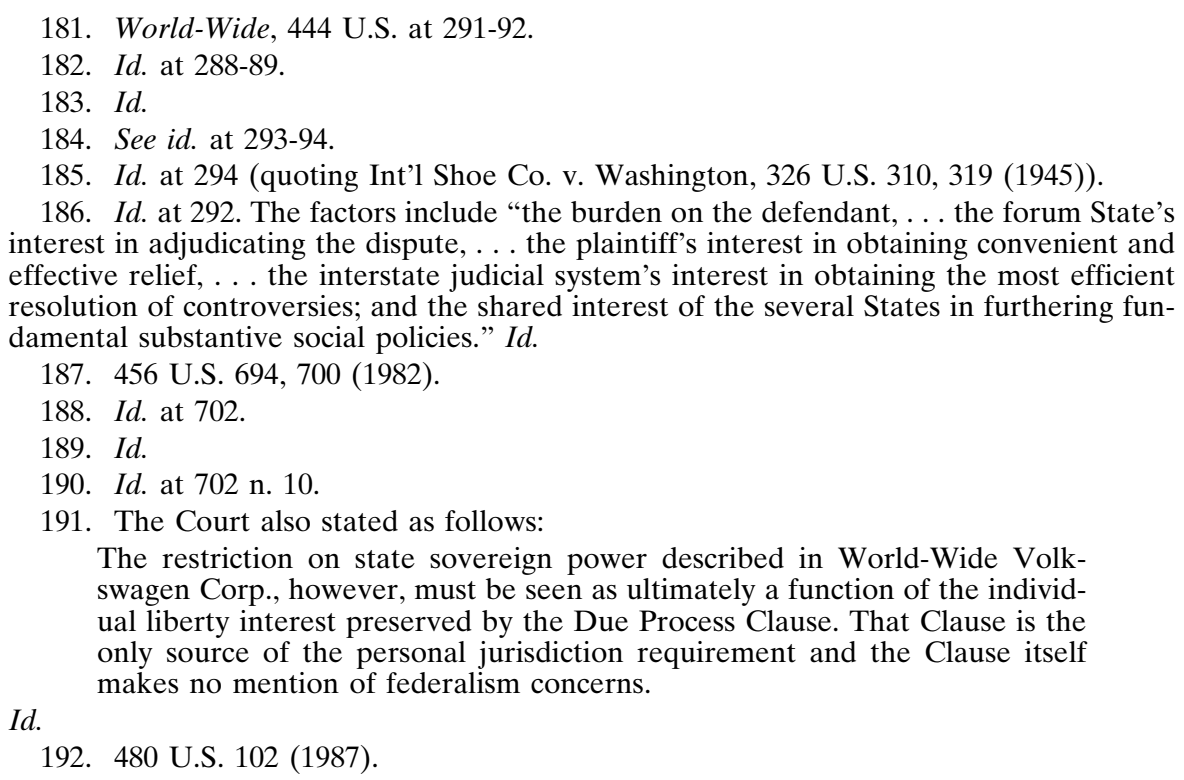


poseful availment. ${ }^{193}$ The disagreement demonstrated continuing differences regarding whether the Due Process Clause, in the personal jurisdiction context, protects primarily interstate federalism interests or individual liberty.

The Court continues to debate the purpose of due process protection of personal jurisdiction. In the 2011 case of J. McIntyre Machinery, Ltd. $v$. Nicastro, ${ }^{194}$ the Court returned a fractured 4-2-3 decision that exposed a continuing deep divide regarding the policies underlying personal jurisdiction and, thus, whether to favor an analysis closer to the forward-looking interpretation of International Shoe or closer to the policies and doctrine underlying Pennoyer $v$. Neff. 195 Justice Kennedy, writing for a four-member plurality, returned overtly to the concepts of sovereignty that informed the Pennoyer $v$. Neff analysis. ${ }^{196}$ Justice Kennedy stated that personal jurisdiction is "a question of [state] authority rather than fairness." 197 Conceding that personal jurisdiction confines judicial power " "not as a matter of sovereignty, but as a matter of individual liberty," "198 the plurality nonetheless emphasized that no judgment can be "lawful" unless the "sovereign has authority to render it."199 Justice Kennedy, thus, determined that "the sovereign" states must have power to exercise personal jurisdiction and, in line with Pennoyer, contended that the defendant must "submit" to the power of a state for personal jurisdiction to be valid. ${ }^{200}$ The defendant could do so in several ways-through express consent; presence within the state at the time of service of process; incorporation or principal place of business in a state; or by "limited" submission through a defendant's purposeful availment of the privilege of conducting activities in a forum, and, in this scenario, only for sufficiently related claims. ${ }^{201}$

193. Compare Asahi Metal Indus. Co., 480 U.S. at 112 (O’Connor, J., plurality opinion) (concluding that " $[\mathrm{t}]$ he placement of a product into the stream of commerce, without more, is not an act of the defendant purposefully directed toward the forum State" and requiring additional conduct by the defendant that would reveal "an intent to serve the market in the forum State"), with id. at 117 (Brennan, J., concurring in part and concurring in judgment) (concluding that no more is required than that "a participant [in the stream of commerce] is aware that the final product is being marketed in the forum State" and that, in these circumstances, suit in the form state is neither a surprise nor a burden unrelated to a forum benefit). See also id. at 122 (Stevens, J., concurring in part and concurring in judgment) (suggesting that the purposeful availment inquiry consider "the volume, the value, and the hazardous character of the components").

194. 131 S. Ct. 2780, 2783 (2011).

195. 95 U.S. 714, 736 (1878); see supra notes $84-86$ and accompanying text (discussing the forward-looking interpretation of International Shoe as supporting an analysis that examined the reasonableness of the forum and its backward-looking face as emphasizing the closeness of defendant's relation to the forum).

196. Nicastro, 131 S. Ct. at 2798-91 (Kennedy, J., plurality opinion).

197. Id. at 2789 (Kennedy, J., plurality opinion).

198. Id. (quoting Ins. Corp. of Ireland, Ltd. v. Compagnie Des Bauxites de Guinee, 456 U.S. 694, 702 (1982)).

199. Id. at 2786-87, 2789.

200. Id. at 2787.

201. Id. at, 2787-88 (Kennedy, J., plurality opinion). 
Justice Ginsburg, writing for the three dissenting justices, argued to the contrary that limits on the personal jurisdiction of state courts protect " 'individual liberty interests," not notions of sovereignty or power. ${ }^{202}$ Justice Ginsburg reemphasized that the critical inquiry is "[t]he relationship among the defendant, the forum, and the litigation," "203 and she underscored that Supreme Court precedent does not support the consent theories endorsed by the plurality. ${ }^{204}$ In her dissenting opinion, Justice Ginsburg applied a reasonableness analysis similar to the analysis used by the Supreme Court in its early post-International Shoe cases to conclude that the defendant at issue should be subject to specific jurisdiction. ${ }^{205} \mathrm{In}$ so doing, Justice Ginsburg also used factors that von Mehren and Trautman predicted would be considered important when the Court had developed a mature specific jurisdiction analysis - the type of claim at issue; the relative burden to plaintiff and defendant in defending in the chosen forum or an alternative forum; whether the parties were individuals or corporations; whether either acted locally or in a pervasively multi-state manner and for economic or other gain; and issues of litigation convenience. ${ }^{206}$ Justice Breyer wrote a separate opinion in which he avoided aligning with either the analysis of Justice Kennedy's plurality opinion or Justice Ginsburg's dissenting opinion. ${ }^{207}$ His opinion created an opaque middle ground. He specifically registered disagreement with the analysis of Justice Kennedy's plurality opinion and contended, instead, that the Nicastro case was easily decided under "our precedents," but he also sided with the plurality to conclude that the defendant was not subject to personal jurisdiction. ${ }^{208}$ 102).

202. Id. at 2798 (Ginsburg, J., dissenting) (quoting Ins. Corp of Ireland, 456 U.S. at

203. Id. (quoting Shaffer v. Heitner, 433 U.S. 186, 204 (1977)).

204. Id. at 2799 .

205. Id. at 2794-97, 2800-04 (2011) (Ginsburg, J., dissenting). Justice Ginsburg concluded that jurisdiction was reasonable in the state where the plaintiff was injured by the foreign defendant's allegedly defective product on the facts at issue, where (1) the defendant was a corporation that treated the United States as a single, national market; (2) the defendant targeted the United States as a whole by seeking to sell products "anywhere in the United States"; (3) the defendant purposefully engaged a domestic distributor to sell products in any state and attended regular product exhibitions in American cities; and (4) the plaintiff was a local actor injured at his jobsite while using defendant's product. $I d$. at 800-04. See also Clermont, supra note 35, at 439-41, 451-55; Effron, supra note 35, at 871$72,892,898-903$ (advocating an enhanced focus on the relation of the lawsuit to the forum, rather than solely on the defendant's relation to the forum, and concluding that Justice Ginsburg's focus on the relation of the suit in fact filed by the injured plaintiff to the forum state at issue would appropriately limit the permissible forums); Lilley, supra note 32, at 113-15 (suggesting that the Court should permit jurisdiction when the defendant could have reasonably foreseen the development of an affiliating link with the forum and the forum is also reasonable); Twitchell, supra note 4, at 658-64, 679-80. See also supra notes 115-147 and accompanying text for a discussion of the use of the reasonableness analysis in the post-International Shoe period.

206. Nicastro, 131 S. Ct. at 2800-04 (citing von Mehren \& Trautman, supra note 10, at 1166-79).

207. Id. at 2793 (Breyer, J., concurring).

208. Id. at 2791-94 (Breyer, J., concurring in judgment). 
Finally, both of the Supreme Court's 2014 personal jurisdiction opinions discuss the purposes underlying due process protection of personal jurisdiction. ${ }^{209}$ Conspicuously absent in each is the territorial power and submission theory of the Nicastro plurality. ${ }^{210}$ Instead, in Daimler AG $v$. Bauman, Justice Ginsburg, in an opinion in which seven other justices joined, stated several times that the restrictive "territorial approach" of Pennoyer $v$. Neff has "yielded to a less rigid understanding" and that specific jurisdiction has been "cut loose from Pennoyer's sway."211 In Walden $v$. Fiore, a unanimous Court indicated that the Due Process Clause protects a liberty interest, but the Walden Court seemed anxious to qualify its conclusion: "Due process limits on the State's adjudicative authority principally protect the liberty of the nonresident defendant-not the convenience of plaintiffs or third parties." 212 Of equal importance, both Bauman, in a general jurisdiction case, and Walden, in a specific jurisdiction case, stated that a court examining specific jurisdiction must consider "the relationship among the defendant, the litigation, and the forum." "213 The Bauman analysis elevates the importance of the controversy to the forum and backs away from a unilateral focus on the relation of the defendant to the forum, ${ }^{214}$ but the Walden Court qualifies its advances. Walden examines the relation of the plaintiff and the litigation to the forum, but limits consideration of each factor to a one-dimensional inquiry regarding whether that factor reveals defendant's contacts with the forum. ${ }^{215}$

What to make of the Court's shifting perspectives on the purposes animating personal jurisdiction? First, it's unlikely that the Court has spoken its last on the issue. Second, the Bauman and Walden opinions signal continued recognition of the individual liberty interest as the primary policy underlying personal jurisdiction, ${ }^{216}$ but Walden, with no principled explanation, also indicates a desire to privilege the defendant's interests. ${ }^{217}$ Third, even if the Court later concludes that both an individual liberty

209. Walden v. Fiore, 134 S. Ct. 1115, 1121-22 (2014); Daimler AG v. Bauman, 134 S. Ct. 746, 753-58 (2014).

210. Walden, 134 S. Ct. at 1123. Walden v. Fiore, however, dealt with alleged intentional conduct, and the Nicastro plurality twice noted that a defendant's alleged intentional misconduct might be an exception to the general requirement that a defendant must submit to the sovereign's authority. Nicastro, 131 S. Ct. at 2785, 2787 (Kennedy, J., plurality opinion).

211. Bauman, 134 S. Ct. at 753-54, 757-58.

212. Walden, 134 S. Ct. at 1122,1125 n.9.

213. Walden, 134 S. Ct. at 1121 (quoting Keeton v. Hustler Magazine, Inc., 465 U.S. 770 , 775 (1984)) Bauman, 134 S. Ct. at 754, 757-58.

214. See infra notes 281 and accompanying text. Likewise, many commentators advocate a greater focus on the relation of the lawsuit to the forum. See, e.g., Brilmayer \& Smith, supra note 61, at 630-32; Clermont, supra note 35, at 439-41, 451-55; Effron, supra note 35, at 897-903; Heiser, supra note 10, at 923, 928-29; Lilley, supra note 32, at 108, 11315; Twitchell, supra note 4, at 646-47, 658-59, 662-63. See also Patrick J. Borchers, Jones v. Flowers: An Essay on a Unified Theory of Procedural Due Process, 40 Creighton L. Rev. 343, 350-52 (2007); Woods, supra note 16, at 890-898, 905.

215. See id.

216. See id. at 1122-25; Bauman, 134 S. Ct. at 760-61.

217. See Walden, 134 S. Ct. at 1122-23. 
interest and an interstate federalism interest underlie personal jurisdiction, the unadorned "purposeful availment" requirement is insufficiently connected to interests of other states or the forum state to serve as an adequate proxy for those interests. Moreover, retaining purposeful availment as an initial prerequisite would also preclude exploration of the "'relationship among the defendant, the forum, and the litigation" that Bauman and Walden endorse. ${ }^{218}$ Fourth, Bauman and Walden provide room for courts to return to a more textured analysis of relevant interests, one that would explore the relation of both the defendant and the lawsuit to the forum. Walden, however, limits examination of factors regarding the relation of the lawsuit to the forum by asking only whether they reveal defendant's contacts to the forum. ${ }^{219}$ Walden's omission of an interstate federalism premise for personal jurisdiction, however, results in an opinion that provides little explanation for favoring primarily the single interest of the defendant. ${ }^{220}$ In the succeeding Sections, I explore the Bauman, Goodyear, and Walden opinions and advocate for an appropriate reasonableness analysis.

\section{A CLOSER LOOK AT BAUMAN, GOODYEAR, AND WALDEN}

\section{A. Bauman and Goodyear: A Restored Narrative Regarding General and SPecific Jurisdiction}

Justice Ginsburg's opinions for eight justices in Bauman and for the unanimous Court in Goodyear put the reasonableness analysis of International Shoe's forward-looking interpretation front and center again-a position it has arguably not held since the Court's decision in Hanson $v$. Denckla. ${ }^{221}$ In these opinions, Justice Ginsburg acknowledges International Shoe as "canonical," and, in each, her analysis begins with and centers on International Shoe. ${ }^{222}$

Although the Court confesses International Shoe as canonical in Bauman and Goodyear, the International Shoe opinion seems-by most definitions-to have lost any such elevated status in the progression of the Court's case-by-case, fact-specific development of personal jurisdiction doctrine and particularly in light of the Hanson v. Denckla decision

218. Id. at 1123 (quoting Shaffer v. Heitner, 433 U.S. 168, 204 (1977)); Bauman, 134 S. Ct. at 754 (quoting Shaffer, 433 U.S. at 204).

219. See Walden, 134 S. Ct. at 1122.

220. See infra notes $380-82$ and accompanying text.

221. 357 U.S. 235, 251-53 (1958); but see Calder v. Jones, 465 U.S. 783, 788-91 (1984); Keeton v. Hustler Magazine, Inc., 465 U.S. 770, 781 (1984).

222. Bauman, 134 S. Ct. at 754 (quoting Goodyear Dunlop Tires Operations v. Brown, 131 S. Ct. 2846, 2853 (2011)). Further, in both the unanimous Goodyear decision and in Justice Ginsburg's dissent in Nicastro, Justice Ginsburg referenced International Shoe as "pathmarking" and relied on it to guide analysis. Goodyear, 131 S. Ct. at 2851; J. McIntyre Mach., Ltd. v. Nicastro, 131 S. Ct. 2780, $2794-95$ (2011) (Ginsburg, J., dissenting). 
and subsequent cases. ${ }^{223}$ Webster's Third New International Dictionary defines "canonical," in part, as "like or conforming to a general rule [;] accorded wide acceptance [;] sanctioned, orthodox, authoritative." 224 The "pedagogical or teaching canon" in constitutional law has been defined as "those cases and materials ... that are regularly taught and read in constitutional law courses, or that should be regularly taught and read in those courses." 225 Under that standard, Professor Erbsen has observed that personal jurisdiction has been exiled from the constitutional canon. ${ }^{226}$ Perhaps it could make a return. Indeed, Bauman suggests a return, in the specific jurisdiction context, to a reasonableness analysis similar to that used pre-Hanson that would examine the relatedness of both the transaction and the defendant to the forum. ${ }^{227}$ Walden also endorses analysis of the relation of the litigation and the defendant to the forum, but it truncated that analysis. ${ }^{228}$ A renewed focus on the reasonableness of the forum could parallel due process protection of the constitutional notice requirement and of procedural due process. ${ }^{229}$

But even solely within the study of personal jurisdiction, the reasonableness analysis of International Shoe's forward-looking approach ceded its authoritative position to Hanson v. Denckla and subsequent cases focusing on territorial authority. Bauman suggests revitalization of International Shoe's focus on the reasonableness of the forum. ${ }^{230}$ Justice Ginsburg's opinions in Bauman and Goodyear confirm restrictions on

223. See supra notes 157-72, and accompanying text for a brief discussion of Hanson and its impact on personal jurisdiction analysis from 1958 through the 2011 decision in Nicastro.

224. Merriam-Webster, Webster's Third New Int'L Dictionary of the English Language Unabridged, 328 (Philip Babcock Cove \& The Merriam-Webster Editorial Staff eds., 2002).

225. J.M. Balkin \& Sanford Levinson, The Canon of Constitutional Law, 111 HARv. L. REV. 963, 1003 (1998).

226. Allan Erbsen, Impersonal Jurisdiction, 60 EMORy L.J. 1, $72-74$ (2010) (suggesting that framing personal jurisdiction issues in the context of broader constitutional debates would influence "how judges and lawyers understand and shape the issue").

227. See Bauman, 134 S. Ct. at 761-62.

228. See Walden, 134 S. Ct. at 1124-25. See Lilley, supra note 32, at 108 (recognizing that, in some cases, the Court's focus on the defendant's forum contacts has made its purported analysis of the "relation among the defendant, the forum, and the litigation" little more than "a hollow refrain").

229. See, e.g., Borchers, supra note 214, at 349-50 (suggesting that the reasonableness factors - " 'the burden on the defendant,' 'the interest forum State's interest in adjudicating the dispute,' 'the plaintiff's interest in obtaining convenient and effective relief,' 'the interstate judicial system's interest in obtaining the most efficient resolution of controversies,' and the 'shared interest of the several States in furthering fundamental substantive social policies" "- parallel the balancing test of Mathews v. Eldridge, 424 U.S. 319, 339-49 (1976), "recast for the issue of the choice of a state forum," and indicating that the requirement of a defendant's "purposeful, claim-related contacts" should be "jettisoned or at least considerably relaxed"); Clermont, supra note 35, at 416, 438, 451 (concluding that the immediate post-International Shoe cases provided that "one should ask whether jurisdiction was reasonable in view of all the interests involved," including those of "the public, the plaintiff, and the defendant" and proposing a return to an analysis based primarily on "fundamental [] fair[ness] in light of all the interests of the public and the parties concerning the litigation"); Rhodes \& Robertson, supra note 79, at 236.

230. See Bauman, 134 S. Ct. at 760. 
general jurisdiction, but they also suggest a broader scope for specific jurisdiction. ${ }^{231}$ Indeed, before addressing the particular general jurisdiction issue presented, each opinion reads like a hornbook on the law of general and specific personal jurisdiction. This is encouraging because commentators have repeatedly concluded that "[m]uch of the problem in defining the scope of general jurisdiction stems from the fact that it is inextricably linked with specific jurisdiction." 232

\section{Bauman and Goodyear: A More Limited Scope for General Jurisdiction}

In Daimler $A G$ v. Bauman, ${ }^{233}$ the Court considered whether continuous and systematic contacts with the state of California by a wholly owned subsidiary of Daimler AG (Daimler) could be imputed to Daimler for the purposes of establishing general jurisdiction over Daimler in California.234 The procedural facts are somewhat complex. Daimler was a German stock company with headquarters in Stuttgart. It manufactured Mercedes-Benz vehicles in Germany. ${ }^{235}$ Daimler's subsidiary, Mercedes Benz-USA, LLC (MBUSA), was a Delaware limited liability corporation with its principal place of business in New Jersey. ${ }^{236}$ Plaintiffs hoped to establish that MBUSA was subject to general jurisdiction in California based on its "continuous and systematic" California contacts. ${ }^{237}$ Those contacts included that MBUSA was Daimler's exclusive importer and distributor in the United States and that MBUSA also had a number of California facilities. ${ }^{238}$ These included "a regional office in Costa Mesa, a Vehicle Preparation Center in Carson, and a Classic Center in Irvine."239 MBUSA was also California's "largest supplier of luxury vehicles," and "over $10 \%$ of" new sales of Mercedez-Benz cars in the United States were in California. ${ }^{240}$ These sales in California constituted $2.4 \%$ of Daimler's total sales worldwide. ${ }^{241}$

Based on MBUSA's "continuous and systematic" contacts in California, plaintiffs alleged that MBUSA was subject to general jurisdiction in California. ${ }^{242}$ They argued further that the general jurisdiction of subsidiary MBUSA should be attributed to Daimler. ${ }^{243}$ From there, Daimler

\footnotetext{
231. See id. at 760-62; Goodyear, 131 S. Ct. at 2855-56.

232. E.g., Borchers, supra note 10, at 120; Twitchell, supra note 4, at 675 .

233. 134 S. Ct. 746, 750-51 (2014).

234. Plaintiffs originally filed suit against DaimlerChrysler Aktiengesellschaft. That entity was restructured in 2007 and is currently known as Daimler AG. Id. at 750-51 n.2.

235. Id. at 750-51.

236. Id. at 751.

237. Id. at 751,752 .

238. Id. at 752 .

239. Id. at 752 .

240. $I d$.

241. Id.

242. Id. Plaintiffs also attempted to obtain personal jurisdiction over Daimler based on its presence in California, but did not appeal the district court's denial of general jurisdiction based on those contacts. $I d$. at 752,758 .

243. Id. at 752 .
} 
should, under principles of general jurisdiction, be subject to suit in California for unrelated conduct in Argentina of another subsidiary. ${ }^{244}$ The Bauman Court held that general jurisdiction was not available because (1) neither Daimler nor MBUSA had its state of incorporation or principal place of business in California;245 and (2) "continuous and systematic" conduct (which, the Bauman Court concluded, generally will define specific rather than general jurisdiction) of Daimler in California did not arise to the level at which Daimler could be considered "essentially at home" there, even assuming that MBUSA's activities could render MBUSA at home in California and assuming also that the activities could be attributed to Daimler. ${ }^{246}$

The Bauman opinion makes two primary assertions about general jurisdiction. First, the Court confirmed the "dispute-blind"/ "dispute-specific" differentiation between general and specific jurisdiction. ${ }^{247}$ Second, Bauman defined more precisely and narrowly the metaphorical "essentially at home" standard for contacts-based general jurisdiction.

\section{a. General Jurisdiction Is "All-Purpose" or "Dispute-Blind"}

In the 1980s, Professor Twitchell reprised the analysis of Professors von Mehren and Trautman regarding the distinction between personal jurisdiction labeled "general" and that labeled "specific."248 "General" jurisdiction, Twitchell reminded, is "based on the affiliations between the forum and one of the parties without regard to the nature of the dispute." 249 "Specific" jurisdiction, by contrast, is "based on affiliations between the forum and the controversy." 250 A court, thus, exercises general or "dispute-blind" jurisdiction if jurisdiction is exercised without regard to the type of claim or dispute at issue. ${ }^{251}$ It asserts specific jurisdiction or "dispute-specific" jurisdiction if "jurisdiction [is] based in any way on the nature of the [claim presented]." 252

In 2011, the Goodyear Court emphatically affirmed the "dispute-blind" concept of general jurisdiction and, correspondingly, a "dispute-specific," or in the Goodyear Court's terminology, a case-linked or controversy-

244. Id. at 758-59. Plaintiffs alleged that the predecessor to Mercedes-Benz Argentina (MB Argentina), an Argentinian subsidiary of Daimler, collaborated in the "kidnap, detention, torture, and" killing of employees of MB Argentina during the "Dirty War" in Argentina, from 1976-1983. Id. at 750-51.

245. Id. at $760-62 \mathrm{nn} \cdot 19-20$

246. Id. at 760-62 (concluding that Daimler's "slim contacts with [California would] hardly render it at home there," even if the Court assumed that MBUSA were at home in California and that MBUSA's California contacts could be attributed to Daimler).

247. See id.

248. Twitchell, supra note 4, at 611 (citing von Mehren \&Trautman, supra note 10, at 1136).

249. Id.

250. Id.

251. Id. at 613 .

252. Id. 
linked vision of specific jurisdiction, ${ }^{253}$ which supports a more expansive reach for specific jurisdiction. The Goodyear Court also emphasized that factors related to the litigation-including the nature of the claim and interests of the plaintiff and the forum state-may bolster assertions of specific jurisdiction, but not general jurisdiction. ${ }^{254}$

Bauman similarly reaffirmed the dispute-blind/dispute-specific differentiation used in Goodyear, ${ }^{255}$ recognizing that general jurisdiction is "all-purpose jurisdiction," while specific is "conduct-linked" and "train[s] on the "relationship among the defendant, the forum, and the litigation." 256 Bauman also indicated a broader scope for specific jurisdiction, stating that specific jurisdiction is at issue when "the suit 'arise[s] out of or relate[s] to the defendant's contacts with the forum.'" 257 Further, in articulating the two-part standard for specific jurisdiction, Bauman omitted a "purposeful availment" requirement (as did Walden v. Fiore), ${ }^{258}$ and posited, in dicta, that the first step is to determine "whether the connection between the forum and the episode-in-suit could justify the exercise of specific jurisdiction." 259 This reliance on a minimum connection between the episode at issue and the forum state is decidedly closer to the reasonableness analysis of McGee than to Hanson's almost exclusive focus on the relationship among the defendant and the forum. ${ }^{260}$

The more expansive articulation of specific jurisdiction arises from the Bauman Court's acceptance of the corollary of Professor Twitchell's contention that general jurisdiction be construed more narrowly to include

253. Goodyear Dunlop Tires Operations, S.A. v. Brown, 131 S. Ct. 2846, 2850-51, 285556 (2011).

254. Id. at 2855. Goodyear stressed that the following issues related to the controversy at issue could be used to bolster a claim of specific jurisdiction, but not general jurisdiction: (1) plaintiff's residence in a forum, $i d$. at 2857 n.5 (citing Calder v. Jones, 465 U.S. 783, 788 (1984); von Mehren \& Trautman, supra note 10, at 1167-73); (2) the state's "'well-recognized interest in providing a forum in which its citizens are able to seek redress for injuries," see id. at 2857 n.5; and (3) issues related to the claim at issues, such as the "[f]low of a manufacturer's products into the forum" in a stream of commerce case. Id. at 2855 (quoting World-Wide Volkswagen, Corp. v. Woodson, 444 U.S. 286, 297 (1980)

(indicating that "where 'the sale of a product ... is not simply an isolated occurrence, but arises from the efforts of the manufacturer or distributor to serve ... the market for its product in [several] States, it is not unreasonable to subject it to suit in one of those States if its allegedly defective merchandise has there been the source of injury to its owner or to others").

Accord Daimler AG v. Bauman, 134 S. Ct. 746, 754 n.5, 757 (2014).

255. Bauman, 134 S. Ct. at, 751, 754, 757 (citing Goodyear, 131 S. Ct. at 2851, 2857; Helicopteros Nacionales de Colombia, S.A. v. Hall, 466 U.S. 408,414 n.9 (1984)).

256. Id. at 751, 757-58, 760; see also Walden v. Fiore, 134 S. Ct. 1115, 1122 (2014); accord Twitchell, supra note 4, at 679-680.

257. Bauman, 134 S. Ct. at 754-55 \& nn.6-7, 761 (emphasis added).

258. Walden, $134 \mathrm{~S}$. Ct. at 1121-22. Walden, however, does require that the defendant have minimum contacts with the forum. Id. at 1119, 1122, 1124-26.

259. Bauman, 134 S. Ct. at 762 n.20.

260. See id. Bauman broadly articulated the first step in a specific jurisdiction analysis to be whether "the connection between the forum and the episode-in-suit could justify the exercise of specific jurisdiction," rather than whether the defendant purposefully availed itself to the forum and, thus, received benefits and privileges of forum law. Id. In the second step, Bauman instructed, a court "consider[s] several additional factors to assess the reasonableness of entertaining the case." Id. 
only jurisdiction based on a party's relation to the forum: ${ }^{261}$ Specific jurisdiction should, correspondingly, be construed more broadly.

\section{b. Bauman Clarifies the "Essentially at Home" Standard}

The Bauman Court also clarified the narrower basis for general or "allpurpose" jurisdiction, emphasizing that a state will have jurisdiction to hear "any and all claims" against a foreign corporation "only when the corporation's affiliations with the State in which the suit is brought are so constant and pervasive 'as to render [it] essentially at home in the forum State.'" 262 It thereafter provided much-needed doctrine to guide a court's construction of the metaphorical "essentially at home" standard. 263

Bauman indicates that "only a limited set of affiliations with a forum" will create general or "all-purpose jurisdiction." 264 A corporate defendant will be "essentially at home" primarily in the "paradigm" instances of general jurisdiction, ${ }^{265}$ or in other forums in which a corporation's affiliations are "comparable" to those of "a domestic enterprise in that State." 266 For individuals, the paradigm instance is the state of domicile. ${ }^{267}$ For corporations, the paradigmatic examples are states of incorporation and principal place of business. ${ }^{268}$ Although Bauman does not limit general jurisdiction exclusively to these paradigm instances, it stresses that finding general jurisdiction outside these cases will require "an exceptional case." 269 Moreover, it indicates that the inquiry extends beyond the extent of a corporation's in-state contacts and requires assessment of all activities of the corporation, including a company's nationwide and worldwide activities, thus emphasizing that a corporation that operates in many states should not be deemed "at home" in all. ${ }^{270}$

261. See id. at 755

262. Bauman, 134 S. Ct. at 751, 754, 758 n.11 (quoting Goodyear, 131 S. Ct. at 2851)); see also id. at 751 (formulating the standard as that general jurisdiction will exist when "the corporation's affiliations with the State ... are so constant and pervasive 'as to render [it] essentially at home in the forum State.", (citations omitted)). Bauman did not reach the issue of the nature of agency relationship that would suffice to impute a subsidiary's forum contacts to its parent. Id. at 759 .

263. Id. at 754 .

264. Id. at 760 .

265. Id. (citations omitted).

266. Id. at $758 \mathrm{n} .11$ (indicating that the "essentially at home" will include other forums in which a corporation has affiliations that are "so "continuous and systematic" " that they are "comparable to a domestic enterprise in that State").

267. Id. at 760 (citing Goodyear 131. S. Ct. at 2853-54).

268. Id. (citing Brilmayer et al, supra note 10, at 735 and referencing Twitchell, supra note 4 , at 633 ).

269. Id. at $761 \mathrm{n} .19$ (indicating that "continuous and systematic" contacts generally indicate specific jurisdiction, rather than general jurisdiction); see id. at $761 \mathrm{nn} .19-20$ (indicating, inter alia, that the Court "do[es] not foreclose the possibility that in an exceptional case,.. . a corporation's operations in a forum other than its formal place of incorporation or principal place of business may be so substantial and of such a nature as to render [it] at home in that State"); see id. at 756 n.8 (indicating that, the Perkins case, the solitary instance in which the Court has found general jurisdiction, was an exceptional case in which the forum could be considered "a surrogate for the place of incorporation or head office" (quoting von Mehren \& Trautman, supra note 10, at 1144)).

270. Bauman, 134 S. Ct. at 762, n.20. 
Bauman further clarified the more limited scope of general jurisdiction by explaining the characteristics and underlying policies associated with being "at home." 271 States of incorporation and principal place of business, Bauman emphasized, each provide instances of affiliations with a forum state that are "unique" because they "ordinarily indicate[] only one place" and they are "easily ascertainable." 272 Additionally, a defendant's home forum provides a plaintiff with at least one certain forum where a defendant may be sued for any claim. ${ }^{273}$

Bauman clarified also that specific (not general) jurisdiction is typically at issue when a corporation "engages in a substantial, continuous, and systematic course of business" in a state. ${ }^{274}$ In accord with its conclusion that International Shoe is "canonical," Bauman narrowed the jurisdiction provided by the terms "continuous and systematic" by referring to their use in International Shoe where, Bauman emphasizes, the Court used "continuous and systematic" only in discussing specific jurisdiction. ${ }^{275}$ To indicate what ultimately has been recognized as general jurisdiction, by contrast, International Shoe used more restrictive language: "instances in which the continuous corporate operations within a state [are] so substantial and of such a nature as to justify suit ... on causes of action arising from dealings entirely distinct from those activities."276

Finally, Bauman also omitted language from prior general jurisdiction opinions that suggested that general jurisdiction could be based (1) on comparison of a defendant's forum contacts to the contacts in Helicopteros and Perkins, repeatedly characterizing Perkins, instead, as the exceptional outlier; 277 (2) on whether forum contacts are sufficient to render a defendant "present",278 or (3) on determination of whether the contacts create "continuous and systematic general business contacts." "279

In summary, Bauman restricted the scope of general jurisdiction and indicated that a defendant's "continuous and systematic" forum contacts will rise to the level of general jurisdiction only in "exceptional" circumstances. ${ }^{280}$ Unless specific jurisdiction is construed more expansively, the Court may have tidied up general jurisdiction doctrine at the expense of

271. Id. at 760 .

272. Id. (referencing Hertz Corp. v. Friend, 559 U.S. 77, 94 (2010)).

273. Id. at 746,760 .

274. Id. at 761 .

275. Id.; accord Twitchell, supra note 4, at 623-25.

276. Bauman, 134 S. Ct. at 761 (quoting Int'l Shoe Co. v. Washington, 326 U.S. 310, 318 (1945) (omitting emphasis added in Bauman)).

277. Compare Bauman, 134 S. Ct. at 755-57 n.8 (shifting focus from whether particular contacts are comparable to Perkins or Helicopteros, to characterization of Perkins as the highly unusual outlier), with Goodyear Dunlop Tires Operations, S.A. v. Brown, 131 S. Ct. 2846, 2856-57 (2011) (assessing the contacts at issue and concluding that, "[m]easured against Helicopteros and Perkins," it would not be permissible "to subject petitioners to general jurisdiction").

278. Goodyear, 131 S. Ct. at 2857.

279. Id. (quoting Helicopteros, 466 U.S. at 416).

280. See generally Bauman, 134 S. Ct. at 761 n.19. 
creating two narrow categories that will often require plaintiffs to pursue defendants in their limited jurisdictional "homes" or other "exceptional" home-like fora, even when it would be entirely reasonable for a court to assert jurisdiction in another state based on the relation of the episode-insuit to the forum. In the next sections, I argue that the Bauman and Goodyear decisions also chart a course for more expansive specific jurisdiction.

\section{Bauman and Goodyear: A More Expansive Specific Jurisdiction}

In Bauman, as in Goodyear, Justice Ginsburg discussed the reach of specific jurisdiction. In Section III.A.2, I note that Bauman construed the supposed "categorical" analysis of International Shoe to classify between categories of specific and general jurisdiction, rather than to create discrete subcategories of specific jurisdiction with particular, required elements. I also explore the Court's return, in Bauman, to more expansive statements regarding the scope of specific jurisdiction. In Section III.B, I examine the Court's application of a truncated reasonableness analysis in Walden v. Fiore and conclude that the Court should return to an interest analysis, but it should not limit the analysis by insisting that each interest reveal forum contacts by defendant.

\section{a. International Shoe's "Categorical" Approach Revisited}

Emphasizing the centrality of International Shoe, ${ }^{281}$ Justice Ginsburg, in Bauman, referenced International Shoe's traditional catechism that a state court may assert personal jurisdiction over a nonresident defendant if the defendant has "certain minimum contacts with [the State] such that the maintenance of the suit does not offend 'traditional notions of fair play and substantial justice.'"282 International Shoe, thereafter, provided guideposts regarding when jurisdiction might be available under this formulation. ${ }^{283}$ Justice Ginsburg also discussed International Shoe's so-called "categorical" analysis, but in Bauman, she applied a lens that envisions a macro approach to the "categorical" analysis. ${ }^{284}$

Justice Ginsburg discussed the "categories" of International Shoe in terms of two overarching categories of personal jurisdiction-specific and general jurisdiction. ${ }^{285}$ She indicated in Bauman that the category of gen-

281. Id. at 754 (quoting Goodyear, $131 \mathrm{~S}$. Ct. at 2853).

282. Id. at 754; accord Goodyear, $131 \mathrm{~S}$. Ct. at 2853 (quoting International Shoe, 326 U.S. at 316).

283. Int'l Shoe Co. v. Washington, 326 U.S. 310, 317-18 (1945); see supra note 109.

284. See generally, Bauman, 134 S. Ct. at 754.

285. Id. at 754-58. Justice Ginsburg, thus, retains the "category" or "classification" terminology of International Shoe and post-International Shoe analysis, but she seems to change the focus by viewing the "classification" at the macro level of specific and general jurisdiction, rather than at the micro level of types of specific jurisdiction. See generally, id. Indeed, at one point, Justice Ginsburg notes that "Plaintiffs have never attempted to fit this case into the specific jurisdiction category." Bauman, $134 \mathrm{~S}$. Ct. at 758. This change of focus provides space for courts to extend application of specific jurisdiction to intermediate or so-called "hybrid" cases. 
eral jurisdiction has become "less dominant" and that of specific jurisdiction has become the "centerpiece," 286 but she made no attempt to divide specific jurisdiction into "subclassifications" or "subcategories" limited to the exemplars referenced in International Shoe, that is, to cases of isolated and casual contacts or continuous and systematic contacts. To the contrary, Justice Ginsburg used expansive language in noting that specific jurisdiction includes both of these instances and more. Bauman provides that specific jurisdiction includes (1) "continuous and systematic" activities in a forum that "g[i]ve rise to the liabilities sued on;" and (2) some "single or occasional acts of the corporate agent in a state" that permit jurisdiction "with respect to suits relating to that in-state activity." 287 Rather than suggesting categorical limitation of specific jurisdiction to these two instances, however, Bauman immediately stated more broadly that specific jurisdiction is at issue when "the suit 'aris[es] out of or relate [s] to the defendant's contacts with the forum." "288 Bauman counsels that specific jurisdiction will encompass many instances of claims "related to" in-state activity, and, thus, also suggests that specific jurisdiction is more aptly likened to a continuum than to a set of discrete subcategories with disqualifying requirements. ${ }^{289}$

In discussing specific jurisdiction, Justice Ginsburg also referenced, in Bauman, an extended passage from von Mehren and Trautman's initial article regarding a state court's specific jurisdiction. ${ }^{290}$ The referenced material indicates that "specific" jurisdiction encompasses differing circumstances, including: (1) various scenarios regarding a defendant's continuous relationship to a forum; (2) various scenarios regarding a defendant's isolated events or transactions in a forum state; and (3) additional scenarios involving multiple or indeterminate parties. ${ }^{291}$ This, too,

286. Bauman, 134 S. Ct. at $755,758$.

287. Id. (quoting International Shoe, 326 U.S. at 317-18 (emphasis added)).

288. Id. (quoting Helicopteros, 446 U.S. 408, 414 n.8 (1984) and citing Goodyear Dunlop Tires Operations, S.A. v. Brown, 131 S. Ct. 2846, 2853 (2011); see also Goodyear, $131 \mathrm{~S}$. Ct. at 2851 (stating that "In contrast to general, all-purpose jurisdiction, specific jurisdiction is confined to adjudication of 'issues deriving from or connected with the very controversy that establishes jurisdiction'") (quoting von Mehren \& Trautman, supra note 10 , at 1136$)$.

289. Compare Richman, supra note 22, at 1339 (observing, inter alia, that "the relationship between the plaintiff's claim and the defendant's forum connections does not fit well into two or even three discrete categories; it resembles a continuum more than a two or three position switch"), with Robert J. Condlin, "Defendant Veto" or "Totality of the Circumstances"? It's Time for the Supreme Court to Straighten out the Personal Jurisdiction Standard Once Again, 54 Cath. U. L. Rev. 53, 58 (2004); Note, Christian E. Mammen, Here Today, Gone Tomorrow: The Timing of Contacts for Jurisdiction and Venue Under 28 U.S.C. \& 1391, 78 CORNELl L. REv. 707, 717-20 (1993) (underscoring the continuing debate regarding whether personal jurisdiction is comprised of discrete "pigeonholes" of jurisdiction or constitutes a continuum and advocating for a version of the "pigeonhole" approach; see also B. Glenn George, In Search of General Jurisdiction, 64 Tul. L. Rev. 1097, 1141 (1990)) (noting that the court, had to date, considered specific and general jurisdiction as separate categories).

290. Bauman, 134 S. Ct. at 754 (citing von Mehren \& Trautman, supra note 10, at 1144$1163)$.

291. See generally id. 
supports a conclusion that specific jurisdiction is not limited to discrete categories or subcategories.

b. Specific Jurisdiction and the Relation Among "the Defendant, the Forum, and the Litigation"

Justice Ginsburg stressed, in Bauman, that specific jurisdiction has become "the centerpiece of modern jurisdiction theory." 292 This seems overstated, given the Court's history of narrowing specific jurisdiction through use of the purposeful availment requirement and its lack of clarity regarding relatedness of claims. Nevertheless, some Supreme Court cases can be marshalled to support an expansive view of specific jurisdiction. Bauman referenced those cases. ${ }^{293}$

Moreover, despite the Supreme Court's ambivalence over the past decades regarding specific jurisdiction, the Bauman Court returned, in deliberate dicta, to previous, more expansive characterizations of specific jurisdiction. Bauman emphasized several times that, after International Shoe, the central inquiry in instances of specific jurisdiction is "the relationship among the defendant, the forum, and the litigation." 294 This language-dicta to be sure-permits courts to refocus the specific jurisdiction inquiry on a consideration of the relation of the defendant to the forum, but also to refocus on the relation of the "litigation" or "controversy" to the forum-just the interests the Court held to control the personal jurisdiction analysis before Hanson v. Denckla. ${ }^{295}$ This was also the recommendation of von Mehren and Trautman, whom Bauman and Goodyear cite frequently and with approval, and it accords with conclusions of some current commentators. ${ }^{296}$

Moreover, in support of its statement that, after International Shoe, "the relationship among the defendant, the forum, and the litigation," has become the central inquiry regarding personal jurisdiction, Bauman also emphasized both (1) that specific jurisdiction extends to cases in which a "suit 'aris[es] out of or relate[s] to the defendant's contacts with the forum[;]" 297 and (2) that, in the area of specific jurisdiction, the Court has moved away from "Pennoyer's rigidly territorial focus." 298 As noted earlier, Bauman also-although, in dicta-reformulated the first portion of the two-part specific jurisdiction inquiry so that it would no longer require a focus on the defendant's purposeful availment, but on connections between the forum and the controversy. First, Bauman states, "a

292. Id. at 749 (citations omitted).

293. Id. at 755 nn.5-6.

294. Id. at 754, 757-58 (each quoting Shaffer v. Heitner, 433 U.S. at 204).

295. See supra notes $117-147$, and accompanying text. Some subsequent cases also privileged the relation of both the defendant and the litigation to the forum. E.g., Calder v. Jones, 465 U.S. 783 (1984); Keeton v. Hustler Magazine, Inc., 465 U.S.770 (1984).

296. Von Mehren \& Trautman, supra note 10, at 1166-76. See, e.g., Effron, supra note 35, at 870-72, 896-98; Lilley, supra note 32, at 113-15; Twitchell, supra note 4, at 679-80.

297. Daimler AG v. Bauman, 134 S. Ct. 746, 754 (2014) (citing Helicopteros Nacionales de Colombia S.A. v. Hall, 466 U.S. 408, 414 n.8 (1984)).

298. Bauman, 134 S. Ct. at 755. 
court is to determine whether the connection between the forum and the episode-in-suit could justify the exercise of jurisdiction" and, second, it "is to consider several additional factors to assess the reasonableness of entertaining the case." 299

Goodyear, similarly, emphasized-also in dicta—that specific jurisdiction is "controversy"-linked ${ }^{300}$ or "case-specific," 301 or "case-linked jurisdiction." 302 The Goodyear opinion repeatedly suggested that it is the broader "litigation," or "suit" rather than "claim" that must be sufficiently related to the forum. ${ }^{303}$ The critical referent, thus, becomes the "episode-in-suit," 304 rather than the "claim," as Goodyear also emphasized that specific jurisdiction derives from or is "connected with" the "very controversy." 305

The broader focus for specific jurisdiction aligns with the Court's specific jurisdiction analysis immediately after International Shoe and before Hanson v. Denckla. Indeed, conspicuous for its absence in Bauman's discussion of specific jurisdiction is Hanson v. Denckla. The Goodyear Court likewise discussed Hanson v. Denckla only briefly, and then just to restrict its application to cases involving isolated or occasional forum contacts. ${ }^{306}$ As will be discussed below, the Walden Court, too, subordinated the purposeful availment inquiry of Hanson, although Walden sought simultaneously to maintain a principal focus on the sufficiency of the defendant's forum contacts. ${ }^{307}$ The Bauman Court, instead of relying on Hanson v. Denckla, cited McGee v. International Life Insurance $e^{308}$ to illustrate the Court's rejection of "Pennoyer's rigidly territorial focus" and the rapid development of specific jurisdiction when "the episode-in-suit occurred in the forum or the defendant purposefully availed itself of the forum." 309 As detailed previously, McGee required assurance that the litigation or "episode-in-suit" was sufficiently related to the forum state to satisfy due process concerns, ${ }^{310}$ but it did so in the context of considering

299. Id. at 762 n.20.

300. Goodyear Dunlop Tires Operations, S.A. v. Brown, 131 S. Ct. 2846, 2851 (2011)

(citing von Mehren \& Trautman, supra note 10, at 1136)).

301. Id. at 2849.

302. Id. at 2851.

303. Id. at $2851,2853,2855$.

304. Id.

305. Id. at 2851 (quoting von Mehren and Trautman, supra note 10, at 1136).

306. Id. at 2854 .

307. See generally Walden v. Fiore, 134 S. Ct. 1115 (2014).

308. 355 U.S. 220, 220 n.6 (1957).

309. Daimler AG v. Bauman, 134 S. Ct. 746, 755 (2014).

310. McGee, 355 U.S. at 223. The McGee Court noted that "[i]t is sufficient for purposes of due process that the suit was based on a contract which had a substantial connection with that State." Id. The Court noted that the insurance contract at issue was delivered in the forum state, the premiums were mailed in the forum, and the insured resided in the forum when he died. Id. Thereafter, the Court considered the interests of the plaintiff, the state, and the defendant and also considered the likely location of witnesses as well as the likelihood that individual plaintiffs would not be able to pursue small or moderate claims if compelled to pursue action against an insurance company in a distant forum. Id. at 223-24. See also Note, supra note 90, at 924 (emphasizing that "other factors [related to the litigation] may tend both to minimize the inconvenience to the defendant and to strengthen the 
a range of relevant interests to determine if jurisdiction was reasonable rather than by focusing principally on the sufficiency of defendant's forum contacts.

In support of Bauman's additional statement that Supreme Court decisions "bear out" von Mehren and Trautman's prediction that specific jurisdiction would "form a considerably more significant part of the [personal jurisdiction] scene," 311 Bauman cited three cases, Asahi Metal Industry Co. v. Superior Court, ${ }^{312}$ Calder v. Jones, ${ }^{313}$ and Keeton v. Hustler Magazine, Inc., ${ }^{314}$ and it referenced expansive dicta from World-Wide Volkswagen. ${ }^{315}$ Admittedly, Bauman discussed these cases in cryptic parentheticals only, ${ }^{316}$ and the cited portion of Justice O'Connor's plurality opinion in Asahi was not applied expansively in that case. In both Calder and Keeton, however, the Supreme Court focused on the relation between the "defendant, forum, and the litigation" to determine if specific jurisdiction was available, and it considered the contours of the particular claim at issue in light of the range of relevant interests rather than solely based on defendant's forum contacts. ${ }^{317}$ This mode of analysis would permit specific jurisdiction to attain the centrality Bauman claims for it.

In Calder v. Jones, for example, a California resident and television performer filed suit, in California courts, alleging libel by the Floridabased writer and editor of an article about her. ${ }^{318}$ Both the writer and editor challenged personal jurisdiction. ${ }^{319}$ The editor, in particular, had few California contacts. ${ }^{320}$ Rather than focusing first and solely on each defendant's purposeful forum contacts, the Court considered the defendants' concededly few contacts with the forum, but in the context of the relationship of the litigation to the forum. ${ }^{321}$ Thus, the Court considered the plaintiffs' many forum contacts, which the Court stressed "may be so manifold" as to permit jurisdiction when it would not otherwise exist; 322 the defendant's conduct, which the Court concluded was "intentional,

\footnotetext{
interests of the plaintiff and of the state so that in some cases it may not be ultimately unfair to subject the defendant to suit even in an inconvenient forum").

311. Bauman, 134 S. Ct. at 755 (citing von Mehren \& Trautman, supra note 10, at 1164.

312. Id. at 755 n.7; 480 U.S. 102, 112 (1987) (plurality opinion of O'Connor, J.).

313. Bauman, 134 S. Ct. at 755 n.7; 465 U.S. 783 (1984).

314. Bauman, 134 S. Ct. at 755 n.7; 465 U.S. 770 (1984).

315. Bauman, 134 S. Ct. 755 n.7; 444 U.S. 286, 297 (1980); see also infra notes 340 to 341, and accompanying text.

316. Bauman, 134 S. Ct. at 755 n.7.

317. Calder, 465 U.S. at 788 (providing that "[i]n judging minimum contacts, a court properly focuses on 'the relationship among the defendant, the forum, and the litigation" ") (quoting Shaffer v. Heitner, 433 U.S. 186, 204 (1977)); Keeton v. Hustler, 465 U.S. 770, 775 (1984).

318. Calder, 465 U.S. at 784-85.

319. Id. at 784-86.

320. Id. Calder, the editor, had been to California only twice-once "on a pleasure trip" and once for testimony in an unrelated case. $I d$. at 786.

321. Id. at 784-88.

322. Id. at 788 .
} 
and ... expressly aimed at California;" 323 and that the claim of libel was strongly related to the state of California, both in terms of development and writing of the allegedly libelous article and of the alleged harm. "The article was drawn from California sources," concerned a California resident, and "the brunt of the" alleged intentional harm would be felt in California where the newspaper in which the article was published had its largest readership. ${ }^{324}$ Under these circumstances and considering the relation to the forum of both the defendants and "the litigation"- -which included the nature of the claim and the interests of the plaintiff and state-the Court concluded that the defendants could reasonably anticipate suit in California. ${ }^{325}$ Personal jurisdiction was appropriate. ${ }^{326}$

In Keeton v. Hustler, ${ }^{327}$ the Court also approved specific jurisdiction over a libel claim, this time based on a claim by a nonresident plaintiff against a defendant magazine that had a limited but regular circulation in the forum state. ${ }^{328}$ Moreover the nonresident plaintiff sought damages allegedly incurred in the forum state and nationwide. ${ }^{329}$ Thus, a portion of the claimed damages would "arise out of" the defendant's conduct in the state, but the "bulk of [the] alleged injuries" had been sustained outside the forum, and, thus, were loosely related only. ${ }^{330}$ Again, the Court stated that, in judging minimum contacts, "a court properly focuses on 'the relationship among the defendant, the forum, and the litigation," "331 and again, the Court examined relevant interests, including the nature of the claim of libel and the interests of the defendant, the plaintiff, the forum state, and other states, as well as concerns regarding where the case could be efficiently litigated. ${ }^{332}$ The Court also indicated that it must be fair to hale the defendant into Court in the forum in light of the defendant's forum contacts and the claim asserted, ${ }^{333}$ but in Keeton $v$. Hustler, this determination would be made in the course of a contextual interest analysis.

The Keeton Court examined the following relevant connections of the defendant and litigation to the forum: (1) the defendant had "continuously and deliberately exploited the New Hampshire market" and could be held to know that New Hampshire followed the "single publication rule," which permitted suit for damages incurred in the forum and all other states; 334 (2) the state's assertion of jurisdiction would serve multi-

323. Id. at 789 .

324. Id. at $788-89$.

325. Id. at 790-91.

326. Id.

327. 465 U.S. 770 (1984).

328. Id. at 770 .

329. Id. at $770-71$.

330. Id. at 773. This illustrates Professor Richman's suggestion that there would be cases in which a part of the claim was related to the forum contacts and other portions might be unconnected or only loosely related. Richman, supra note 22, at 1340.

331. Keeton, 465 U.S. at 775.

332. Id. at $775-78$.

333. Id.

334. Id. at 781 . 
ple state interests - the forum state's " "especial interest in exercising . . . jurisdiction over those who commit torts within its territory;" "335 a forum state interest in safeguarding its citizens from the deception of libel and in protecting nonresidents from libel's reputation-diminishing effects within the state; and an interest in cooperating with other states-through the single publication rule - to litigate in a single lawsuit all issues arising from a libel claim; 336 and (3) the lesser, but not nonexistent, interest of the nonresident plaintiff who sued for libel in the only forum in which the statute of limitations had not run. ${ }^{337}$ Moreover, the Court emphasized the efficient litigation concerns served by the "single publication rule" of limiting duplicative lawsuits and precluding harassment of defendants. ${ }^{338} \mathrm{Af}-$ ter considering these multiple relevant factors, the Court concluded that due process permitted jurisdiction. ${ }^{339}$

In emphasizing the centrality of specific jurisdiction, Bauman also referenced expansive dicta from World-Wide Volkswagen Corp. v. Woodson that would permit personal jurisdiction over claims against a product manufacturer or distributor in the state of an accident involving the product, even if the product had been sold in another state. ${ }^{340}$ Jurisdiction would be permissible, under the World-Wide dicta, if the manufacturer or distributor had taken efforts in another forum to serve, directly or indirectly, the market for its product in the forum state:

[I]f the sale of a product of a manufacturer or distributor such as Audi or Volkswagen is not simply an isolated occurrence, but arises from the efforts of the manufacturer or distributor to serve, directly or indirectly, the market for its product in other States, it is not unreasonable to subject it to suit in one of those States if its allegedly defective merchandise has there been the source of injury to its owner or to others. ${ }^{341}$

In summary, the Bauman Court discussed specific jurisdiction in expansive terms. Bauman also referenced cases in which the Court based specific jurisdiction on the relation of the defendant and the litigation to the forum, rather than focusing solely on the defendant's forum contacts. In the Court's second 2014 personal jurisdiction decision, Walden v. Fiore, the Court also used language that moved toward a reasonableness analysis, but Walden ultimately applied that analysis narrowly.

335. Id. at 776 (quoting Leeper v. Leeper, 114 N.H. 294, 298, 319 A.2d 626, 629 (1974)).

336. Id. at 776-78.

337. Id.

338. Id. $777-78$.

339. Id. at 781 .

340. Daimler AG v. Bauman, 134 S. Ct. 746, 755 (2014) (citing World-Wide, 444 U.S. 286, 297 (1980)).

341. Id. at 755 n.7 (quoting World-Wide Volkswagen Corp. v. Woodson, 444 U.S. 286, 297 (1980)). See also J. McIntyre Mach., Ltd. v. Nicastro, 131 S. Ct. 2780, 2802 (2011) (Ginsburg, J., dissenting) (construing the World-Wide dicta to provide that "when a manufacturer or distributor aims to sell its product to customers in several States, it is reasonable 'to subject it to suit in [any] one of those States if its allegedly defective [product] has there been the source of injury" (quoting World-Wide, 444 U.S. at 297)). 


\section{B. Walden v. Fiore-A Renewed Reliance on the "Relation Among the Defendant, the Forum, and the Litigation"}

\section{The Walden Opinion}

Supporting the more expansive specific jurisdiction discussed in Bauman, the Supreme Court affirmed, in Walden v. Fiore, that specific jurisdiction focuses on "the relationship among the defendant, the forum, and the litigation." 342 The Walden Court also indicated, in line with a reasonableness approach, that due process protections underlying personal jurisdiction primarily protect a "liberty interest," though, Walden emphasized, "principally ... the liberty interest of the nonresident defendant-not the convenience of plaintiff or third parties." 343 Additionally, the Walden Court stated that, for a state to assert personal jurisdiction consistent with the Due Process Clause, "the defendant's suit-related conduct must create a substantial connection with the forum." 344 Much of the language in the Walden opinion accords with the return of the forward-looking interpretation of International Shoe to a place of prominence. The Court also reached an acceptable result. However, as in prior opinions, the Walden Court seeks to have it both ways-here, examining a number of reasonableness factors in its due process analysis, but also insisting, without adequate justification, on viewing all interests through a defendant-focused lens, which accords with the restrictive interstate federalism approach. ${ }^{345}$

342. Walden v. Fiore, 134 S. Ct. 1115, 1121, 1126 (2014).

343. Id. at 1122,1125 n.9.

344. Id. at 1121-22 n.6. The Walden Court indicated also that specific or case-linked jurisdiction depends on an afiliatio[n] between the forum and the underlying controversy (i.e., an activity or an occurrence that takes place in the forum State and is therefore subject to the State's regulation) (internal quotations omitted).

345. See, e.g., Walden, $134 \mathrm{~S}$. Ct. at 1124 (indicating that the "proper lens" for determining personal jurisdiction is to focus on "whether the defendant's actions connect him to the forum" (emphasis in Walden opinion). First, the Walden Court assessed defendant's relations with the forum but concluded that "no part of [his] course of conduct occurred in Nevada," and, because "defendant's actions [did not] connect him to the forum," defendant had "no jurisdictionally relevant contacts with Nevada." Walden, 134 S. Ct. at 1124. Second, Walden examined defendant's relationship with the resident plaintiffs, and specifically considered that defendant knew plaintiffs had "strong forum connections" in Nevada when he directed at them his conduct of drafting the allegedly false probable cause affidavit. Id. Walden concluded, however, that these factors "obscure[] the reality that none of [defendant's] challenged conduct had anything to do with Nevada itself." Id. at 1125. Third, the Court considered the nature of the intentional constitutional torts alleged and that, as in Calder v. Jones, the plaintiffs in Walden suffered injury in the forum state from defendant's conduct in Georgia. Id. The Court rejected this as providing insufficient connection to the forum because, the Court concluded, "[r]egardless of where a plaintiff lives or works, an injury is jurisdictionally relevant only insofar as it shows that the defendant has formed a contact with the forum State." Id. Fourth, still considering the claim at issue, the Walden Court stated that, even if it were to consider the "continuation of the seizure in Georgia to be a distinct injury, it is not the sort of effect that is tethered to Nevada in any meaningful way." Id. Thus, the Court considered many factors relevant to an interest analysis, but discounted all because they did not show connection of the defendant to the forum. See Lilley, supra note 32, at 108 (concluding that the Courts insistence on focusing on the defendant and essentially asking whether the defendant is present in the forum renders its 
In Walden, plaintiffs, who had residences in Nevada and California, filed suit in federal court in Nevada against defendant Walden, a Georgia police officer. ${ }^{346}$ The alleged claims arose from actions Walden took while acting as a deputized agent for the Drug Enforcement Agency (DEA). ${ }^{347}$ Plaintiffs, professional gamblers, were returning from a gambling trip to Puerto Rico with cash that constituted their "bank" and winnings. ${ }^{348}$ They alleged intentional violations of their Fourth Amendment rights, arising from Walden's seizure in Georgia of approximately $\$ 97,000$ following a search of plaintiffs at an Atlanta airport. ${ }^{349}$ Walden seized the money; he later engaged in conversations with plaintiffs' Nevada attorney about the source of the funds; and still later, he helped draft an affidavit showing probable cause for forfeiture of the money, which he forwarded to the United States Attorney's Office. ${ }^{350}$ Ultimately, no forfeiture complaint was filed, and plaintiffs' money was returned. ${ }^{351}$

Plaintiffs alleged the following intentional constitutional infractions: (1) Walden seized their cash without probable cause; (2) he kept the money after determining it was not related to drug activity; (3) he helped draft and then provided to the U.S. Attorney a probable cause affidavit to support a forfeiture action although he knew the affidavit contained false information; (4) he acted willfully in seeking forfeiture while, at the same time, withholding exculpatory information; and (5) he failed to give available exculpatory information to the United States Attorney's Office. ${ }^{352}$ Plaintiffs contended that personal jurisdiction was appropriate in Nevada because Walden knew when he drafted the probable cause affidavit that they were connected with Nevada and knew a delay in delivering their funds would harm them in Nevada. ${ }^{353}$ A divided panel of the Ninth Circuit concluded that jurisdiction was proper over portions of the case based on the "false probable cause affidavit" "because, by submitting the affidavit while knowing that the plaintiffs had "significant connections" to Nevada, Walden had "expressly aimed" his conduct at Nevada. ${ }^{354}$

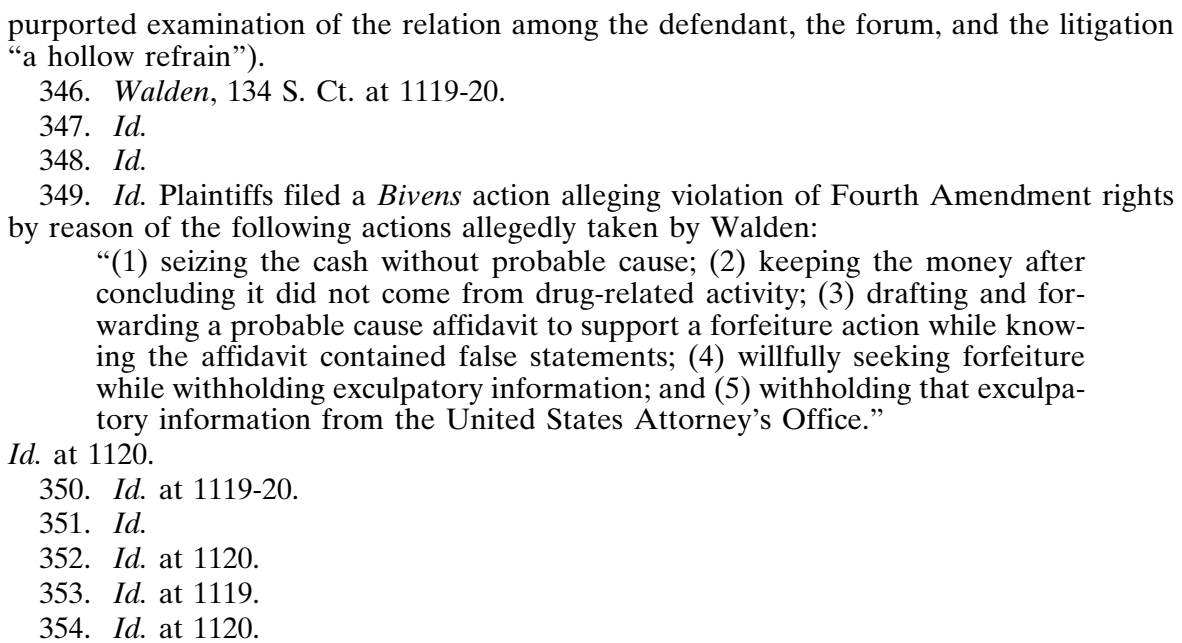


Justice Thomas, writing for the unanimous Walden Court, stated that whether a state may assert specific jurisdiction in a particular case "focuses on 'the relationship among the defendant, the forum, and the litigation;" 355 and that "the defendant's suit-related conduct must create a substantial connection with the forum."356 The Walden Court cited World-Wide and Hanson v. Denckla, not as imposing an initial requirement to find sufficient "purposeful availment" before a court may assess the relation of the controversy to the forum, but as requiring (1) that the relation with the forum state "must arise out of contacts that the "defendant himself' creates with the forum State";357 and (2) that "our 'minimum contacts' analysis looks to the defendant's contacts with the forum State itself, not the defendant's contacts with persons who reside there." 358 Walden also referenced portions of Burger King Corp. v. Rudzewicz ${ }^{359}$ to support the first statement, but Burger King is more nuanced, providing also that "[j]urisdiction is proper ... where the contacts proximately result from actions by the defendant himself that create a 'substantial connection' with the forum State." 360 Burger King also provided that the "fair warning requirement" of the Due Process Clause is met when a defendant "has purposefully directed his activities at residents of the forum, . . . and the litigation results from alleged injuries that arise out of or relate to those activities." 361 Burger King, thus, supports Walden's recognition that a defendant's forum contacts may "intertwine [ ] with . . . transactions or interactions with the plaintiff or other parties." 362 With respect to the second statement, in which Walden emphasizes that the "minimum contacts" analysis focuses on the defendant's contacts with the forum rather than those residing there, the Walden

355. Id. at 1121 (quoting Keeton v. Hustler Magazine, Inc., 465 U.S. 770, 775 (1984).

356. Id. But see McGee v. Int'l Life Ins. Co., 355 U.S. 220, 223 (1957) (concluding that it "is sufficient for purposes of due process that the suit was based on a contract which had substantial connection with [the forum] [s]tate" (emphasis added)).

357. Walden, 134 U.S. at 1122 (citing Burger King Corp. v. Rudzewicz, 471 U.S. 462, 475 (1985))

358. Id. (citing International Shoe, Hanson, and other prior Supreme Court cases in support of the proposition that "our 'minimum contacts' analysis looks to the defendant's contacts with the forum State itself, not the defendant's contacts with persons who reside there").

359. Burger King, 471 U.S. at 475.

360. Id. (quoting McGee v. Int'l Life Ins. Co., 355 U.S. 220, 223 (1957) and referencing Kulko v. Cal. Super. Ct., 436 U.S. 84, 94 n.7 (1978) (first emphasis added)).

361. Id. at 472 (emphasis added); see also id. at 476 (concluding that "[s]o long as a commercial actor's efforts are 'purposefully directed' toward residents of another State, we have consistently rejected the notion that an absence of physical contacts can defeat personal jurisdiction"). Burger King also concluded that the "fairness factor" considerations sometimes will demonstrate the fairness of litigation on a lesser showing of minimum contacts, and that, if a defendant "purposefully has directed his activities at forum residents ... he must present a compelling case that the presence of some other considerations would render jurisdiction unreasonable." Id. at 477-78 (citations omitted).

362. Walden, 134 S. Ct. at 1123 (2014) (citing Rush v. Savchuk, 444 U.S. 320, 332 (1980)); Goodyear, at 2857 n.5 (2011) (noting that "[w]hen a defendant's act outside the forum causes injury in the forum, . . . a plaintiff's residence in the forum may strengthen the case for the exercise of specific jurisdiction") (citing Calder v. Jones, 465 U.S. 783, 788 (1984) and von Mehren \& Trautman, supra note 10, at 1167-73)). 
Court returned to an analysis the Court has used to protect interstate federalism interests rather than the liberty interest Walden espouses. ${ }^{363}$ Indeed, the Court's previous cases analyzing the liberty interest focus on a broad-based analysis of connections of the controversy, the defendant, and the plaintiff to the state, as well as issues of litigation convenience.

Walden did, in fact, examine multiple factors important to a reasonableness analysis. It examined the defendant's relation to the forum, the relation of the claim to the forum, and the plaintiffs' relation to the forum and the defendant. ${ }^{364}$ It limited its assessment of each factor, however, by insisting that a court must determine primarily whether "the defendant's actions connect him to the forum." 365 This Walden referred to as the "proper lens" for the analysis, ${ }^{366}$ but again, that lens is tied to a vision of interstate federalism, not the liberty interest, as driving the due process analysis.

Thus constrained to consider multiple factors but only for evidence of defendant's forum contacts, Walden could not fully examine the relation of the defendant or the controversy to the forum as the Supreme Court did in Calder v. Jones - the primary case to which Walden turns for analogy. ${ }^{367}$ Instead, Walden emphasized that defendant Walden's conduct all occurred in Georgia and could supply no contact between the defendant and Nevada: Defendant approached, questioned, and searched plaintiffs in Georgia rather than in the forum state of Nevada; he seized the cash in Georgia; and he also assisted in writing the allegedly false probable cause affidavit and sent it the US. Attorney's Office in Georgia. ${ }^{368}$ From these facts, the Walden Court identified "no jurisdictionally relevant contacts with Nevada."369

The Court also examined Walden's relation with plaintiffs and his knowledge of their relation with the forum. ${ }^{370}$ Here, the Court addressed plaintiffs' argument that Walden had sufficient contacts with Nevada because he took intentional action that would affect them, knowing they had strong Nevada connections and they would suffer injury in Nevada

363. Walden, 134 S. Ct. at 1122. Walden here references one of the statements in Hanson v. Denckla, 357 U.S. 235, 251 (1958), that supported protecting interstate federalism interests: "However minimal the burden of defending in a foreign tribunal, a defendant may not be called upon to do so unless he has had the 'minimal contacts' with that State that are a prerequisite to its exercise of power over him." Id. This authority is inapposite because Hanson was premised on the view that the Due Process Clause, in the personal jurisdiction context, protected primarily interstate federalism interests, i.e., the "territorial limitations on the power of the respective States," Hanson, 357 U.S. at 251, rather than a liberty interest-whether of the defendant or others.

364. Walden, 134 U.S. at 1124.

365. Id.

366. Id.. Purporting to examine the liberty interest, Walden concluded that the defendant lacked "the 'minimal contacts' with Nevada that are a prerequisite to . . jurisdiction," which is an interstate federalism analysis. Id.

367. Id. at 1123-25.

368. Id.

369. Id. at 1124 .

370. Id. 
from wrongful conduct. ${ }^{371}$ The Walden Court concluded that this argument "improperly attributes a plaintiff's forum connections to the defendant" and "obscures" that defendant's conduct had nothing "to do with Nevada itself." 372 The Court's conclusory observations provide little analysis of when and why the plaintiff's interactions with a nonresident defendant matter, though the Walden Court did acknowledged the relevance of such interactions. ${ }^{373}$ Instead, the Court simply refocused on the fact that defendant's actions occurred in another state.

As in Calder, the Walden Court also considered that the harm to plaintiffs (deprivation of ability to use their money) caused by defendant's alleged intentional conduct would be felt in the forum state, here Nevada. The Walden Court concluded that the location in which plaintiffs suffered injury would be relevant only if it showed that defendant had "formed a contact with" Nevada, ${ }^{374}$ that is, if it showed that "defendant's conduct connects him to the forum in a meaningful way." 375 The Court found no "meaningful" connection because plaintiffs would have suffered injury in any forum to which they chose to travel and use their money. ${ }^{376}$ But Walden again limited its consideration to whether the plaintiffs' in-state harm revealed forum contacts by defendant rather than considering whether that harm, combined with Walden's knowledge at the time of the alleged intentional actions that plaintiffs had returned to Nevada, could create sufficient "contacts, ties, or relations" to Nevada. ${ }^{377}$ The Walden Court, thus, concluded that the defendant "lack[ed] the 'minimal contacts' with Nevada that are a prerequisite to the exercise of jurisdiction over him." 378 The opinion ultimately devalued the connection of the plaintiff and the controversy to the forum and relied solely on counting defendant's forum contacts. Of particular disappointment, the opinion did not explain why the connection of the plaintiff and the controversy are unimportant. Nor did it shed light on how its conclusory analysis should be used in future cases to determine whether a defendant's contacts are sufficient.

\section{The Walden Critique}

The Walden Court reached an acceptable conclusion on the facts at issue, it articulated an overall correct approach of assessing concurrently the relation of both the defendant and the litigation to the forum, and it correctly declined to impose an initial requirement of finding "purposeful availment." The Court's analysis, however, was inapt in several respects-(1) in limiting the liberty interest primarily to protection of the

371. Id. at $1123-25$.

372. Id. at 1125. See also supra note 345.

373. Walden, $134 \mathrm{~S}$. Ct. at 1123.

374. Id. at 1125 . See also supra note 345.

375. Walden, $134 \mathrm{~S}$. Ct. at 1125.

376. Id.

377. Int'l Shoe Co. v. Washington, 326 U.S. 310, 319 (1945).

378. Walden, $134 \mathrm{~S}$. Ct. at 1124. 
defendant; (2) in considering, but obscuring and curtailing analysis of, factors related to the reasonableness of the forum, and ultimately examining only the one-dimensional issue of the sufficiency of defendant's contacts with the forum; and (3) in failing to provide guidance to lower courts.

a. Walden Inappropriately Limits Due Process to Protecting "Principally" the Defendant's Liberty Interest

Having recognized the Due Process Clause as protecting a liberty interest, the Walden Court inappropriately limited its analysis to "principally protect the liberty of the nonresident defendant-not the convenience of plaintiffs or third parties." 379

First, Walden supplied no rationale for the decision to protect "principally" the defendant's liberty interest when examining the relation among the defendant, the forum, and the litigation. The Court did not indicate that enhanced protection of the defendant's interest was necessary to protect interstate federalism interests, ${ }^{380}$ to protect the defendant's convenience, ${ }^{381}$ or to ensure fair notice to the defendant. ${ }^{382}$ The Court did include snippets from prior opinions indicating a need to ensure that defendant has forum contacts or connections, ${ }^{383}$ but again provided no foundation-theoretic or pragmatic-for focusing solely on the sufficiency of defendant's forum contacts.

Walden cited World-Wide twice for the proposition that the due process limitation on state personal jurisdiction protects "principally . . . the liberty of the nonresident defendant—not the convenience of the plain-

379. Id. at 1122,1125 n.9.

380. Though the court has vacillated on whether the Due Process Clause protects interstate federalism interests, see supra notes 155-212 and accompanying text, the Walden Court emphasized that the focus of the Due Process Clause for personal jurisdiction purposes is protection of the liberty interest. Walden, $134 \mathrm{~S}$. Ct. at 1122, 1125 n.9.

381. The Supreme Court has several times indicated that "modern transportation and communication" have lessened the burden of litigation in a foreign forum. E.g., Burger King Corp. v. Rudzewicz, 471 U.S. 462, 474 (1985); World-Wide Volkswagen Corp. v. Woodson, 444 U.S. 286, $292-93$ (1980) (quoting McGee v. Int'l Life Ins. Co, 355 U.S. 220, 222-23 (1957)). Further, scholars have noted the relative convenience of most forums; that parties need not and do not relocate to pursue or defend litigation; that they need not be present in a state during most phases of the litigation process; and that they often hire local counsel. E.g., Borchers, supra note 65, at 94-100. Thus, commentators have concluded that the Due Process Clause would set a very high standard for invalidation of a forum based on defendant's inconvenience. See, e.g., id. (noting that some scholars have suggested a standard of "practical inability to defend" and advocating that standard plus a showing of an alternative forum "in which plaintiff can meaningfully pursue the claim," which would create a limited constitutional forum non conveniens doctrine); Heiser, supra note 10, at 935-36 (suggesting a standard that litigation in the forum "be so manifestly and gravely inconvenient that the defendant will be effectively deprived of a meaningful day in court"). The Supreme Court has also indicated occasionally that motions for change of venue could resolve inconvenience issues. See Burger King, 471 U.S. at 477.

382. The Court has previously identified "fair notice" as the basis for the purposeful availment requirement. That premise has been repeatedly criticized because, among other reasons, potential defendants receive fair notice of when they will be subject to suit through Supreme Court opinions. See supra notes 64-65 and accompanying text.

383. See infra notes 357-363 and accompanying text. 
tiffs or third parties." 384 Walden, thus, protected the defendant's interest by invoking World-Wide Volkswagen for the assertion that due process principally protects "the liberty of the nonresident defendant." 385 Walden, however, failed to acknowledge the entirety of World-Wide's discussion of the liberty interest. The World-Wide Court, in fact, concluded that protection of the defendant against an inconvenient forum is referred to as a "reasonableness" or "fairness" inquiry, ${ }^{386}$ and that it is "implicit" in the reasonableness analysis that the court will, in appropriate cases, consider "other relevant factors," including the burden on defendant, the interest of the forum state, the plaintiff's interest, the interest of other states in the "most efficient resolution of controversies," and the shared interest of states in furthering fundamental substantive social policies. ${ }^{387}$ In devaluing, theses interests, the Walden Court parts company with the Court's prior liberty interest precedent.

Finally, the Supreme Court has recognized that the Due Process Clause protects plaintiffs as well as defendants in the personal jurisdiction context. 388 Supreme Court opinions from which the Court's liberty interest analysis was drawn also directly assessed the comparative ability of the plaintiff to sue in the defendant's home forum in the case at issue and the

384. Walden v. Fiore, 134 S. Ct. 1115, 1122, 1125 n.9 (2014) (referencing World-Wide Volkswagen Corp. v. Woodson, 444 U.S. 286, 291-92 (1980)).

385. Id.

386. World-Wide, 444 U.S. at 292. Walden referenced a portion of World-Wide that concluded that the "concept of minimum contacts," in part, "protects the defendant against the burdens of litigating in a distant or inconvenient forum." Walden, $134 \mathrm{~S}$. Ct. at 1122; World-Wide 444 U.S. at 291-92. World-Wide also indicated, however, that this "protection against inconvenient litigation" is often referred to "in terms of 'fairness' or 'reasonableness.'" World-Wide, 444 U.S. at 292. In this analysis, "the relationship" of the defendant to the forum must indicate that "it is "reasonable ... to require the corporation to defend the particular suit'" there. Id. at 292 (quoting Int'l Shoe Co. v. Washington, 326 U.S. 310, 317 (1945)). Importantly, however, the World-Wide also emphasized that interests of plaintiffs and various states and efficiency concerns would be part of the reasonableness calculation regarding whether the particular forum is reasonable for the particular case. $I d$. at 292. World-Wide recognized that the burden on defendant would always be a "primary concern," but found it "implicit" in a reasonableness analysis that other interests, including the following, would be considered in appropriate circumstances:

the forum State's interest in adjudicating the dispute, see McGee v. International Life Ins. Co., 335 U.S. 220, 223 . . . (1957); the plaintiff's interest in obtaining convenient and effective relief, see Kulko v. California Superior Court, supra, 436 U.S., at $84,92 \ldots$ at least when that interest is not adequately protected by the plaintiff's power to choose the forum, $c f$. Shaffer $v$. Heitner, 433 U.S. 186, 211 n. 37 . . (1977); the interstate judicial system's interest in obtaining the most efficient resolution of controversies; and the shared interest of the several States in furthering fundamental substantive social policies, see Kulko v. California Superior Court, supra, 436 U.S., at 93

$I d$. at 292. Thus, in this attempt to provide virtually unilateral protection for the liberty interest of the defendant, the Walden Court parts company with the Court's prior cases, which would consider the burden on defendant in light of relevant interests. E.g. Asahi Metal Indus. Co. v. Superior Court, 480 U.S. 102, 115 (1987) (mentioning World-Wide case); see also Burger King Corp. v. Rudzewicz, 471 U.S. 462, 476-77 (1985).

387. World-Wide, 444 U.S. at 292.

388. Phillips Petroleum v. Shutts, 472 U.S. 797, 807, 811-12 (1985). See also Mullane v. Cent. Hanover Bank \& Trust Co. 339 U.S. 306 (1950). 
defendant's ability to litigate in plaintiff's chosen forum. ${ }^{389}$ Commentators have, similarly, increasingly concluded that the personal jurisdiction assessment should include a comparative assessment of the interests and convenience of the defendant and plaintiff. 390 The "symmetry" of the positions of plaintiffs and defendants is hard to ignore: "If the forum exercises jurisdiction, then the defendant must travel to the forum to litigate; if the forum does not exercise jurisdiction, then it is the plaintiff that must travel." 391 And the Court has, of course, continued to indicate that, in appropriate cases, courts should consider interests of the plaintiff, interests of relevant states, and considerations regarding efficient litigation as well as the burden on defendant. ${ }^{392}$

Indeed, Walden seems implicitly to have made a comparative assessment of the relative ability of defendant and plaintiffs to litigate in the distant alternative forums in the course of its consideration of the relation of the claim to Nevada and of the sufficiency of defendant's connection to the forum. It concluded that, in these circumstances and on this claim, the considerations favored the defendant and a denial of personal jurisdiction.

\section{b. Walden, the Liberty Interest, and the Reasonableness Inquiry}

An initial reading of the Walden opinion also suggests that the Court did not consider factors previously deemed relevant to a liberty interest analysis-factors regarding the plaintiff's interest; the claim's relation to the forum state and, thus, the interests of the relevant states; and the interests of the several states in the efficient litigation of the controversy, in favor of sole analysis of contacts that the defendant himself creates with the forum state. This would be odd for a Court ostensibly committed to a "liberty interest" analysis, even one that put a principal focus on the defendant's interests. The Court does, in fact, consider several of those factors, though only in determining if they reveal contacts by defendant

389. World-Wide, 444 U.S. at 292; accord Kamp, supra note 32, at 39. See also supra notes 121-147, and accompanying text, for an analysis of the following cases in which the Court considered the relative ability of the plaintiff and defendant to sue in alternative forums: McGee v. Int'l Life Ins. Co., 355 U.S. 220 (1957); Travelers Health Ass'n v. Virginia, 339 U.S. 643 (1950); Mullane, 339 U.S. at 306-13.

390. See Brilmayer \& Smith, supra note 61, at 630-33 (reminding that the Due Process Clause protects plaintiffs as well as defendants and advocating for comparison, in appropriate cases, of defendant's contacts with plaintiff's chosen forum with plaintiff's contacts with the alternative forum); Clermont, supra note 35, at 451-52 \& n.201; Jay, supra note 65, at 459; Note, supra note 90, at 924; von Mehren \& Trautman, supra note 10, at 1166-76; Woods, supra note 16, at 892-93. The Supreme Court has also recognized the importance of a comparative evaluation of fairness of forum. E.g., Burger King, 471 U.S. at 478 (stating that jurisdiction may not be used to "make litigation 'so gravely difficult and inconvenient' that a party unfairly is at a "severe disadvantage' in comparison to his opponent" (citing, inter alia, McGee v. Int'l Life Ins. Co., 355 U.S. 220, 223-24 (1957)); see Woods, supra note 16 , at $892-93$.

391. Brilmayer \& Smith, supra note 61, at 630.

392. E.g., Asahi Metal Indus. Co. v. Superior Court, 480 U.S. 102, 113 (1986); Burger King, 471 U.S. at 477-78; World-Wide Volkswagen Corp. v. Woodson, 444 U.S. 286, 292 (1980). 
with the forum. The Court considered the plaintiffs' relation to the defendant and to Nevada; the relation of the claim to the forums of Nevada and Georgia; and defendant's relation to Nevada and Georgia. ${ }^{393} \mathrm{Be}-$ cause the Walden Court considered each factor in isolation and each only for purposes of determining if defendant had forum contacts, the reasonableness factors seemed almost to be nonexistent. Moreover, considered in this fashion, the opinion is unpersuasive, and it provides no assistance in determining the rationale for the Court's decision that defendant's contacts with Nevada were insufficient to authorize personal jurisdiction. The remedy for these ills is for the Court to fully assess the interests of the "reasonableness" analysis.

\section{c. Walden Provides Little Guidance to Lower Courts}

The Walden Court ultimately failed to provide guidance to lower courts regarding whether a defendant has the requisite "substantial connections" with the forum, other than (1) that courts should focus on whether defendant's "suit-related conduct . . . create[d] a substantial connection with the forum State," (2) that the defendant's relation to the forum should "arise out of contacts that the 'defendant himself' creates with the forum"; and (3) that, defendant's "effects ... on [plaintiffs] [we]re not connected to the forum State in a way that makes those effects a proper basis for jurisdiction." 394 These conclusory statements obscure the basis for the decision, continue the ambiguity that has characterized the Court's minimum contacts analysis, and provide no principled basis for lower courts to assess subsequent cases.

Assessment of whether specific jurisdiction is available would be better protected by a richer analysis of the relation among the defendant, the forum, and the litigation-one that overtly and fully examines the nature of the controversy or lawsuit and its connections to the forum as well as the relation of the defendant to the forum. This analysis would broaden specific jurisdiction, but consideration of the factors important to a reasonableness or fairness analysis would also put appropriate limits on specific jurisdiction. ${ }^{395}$ It would also provide needed guidance to lower courts. The analysis would examine concurrently the relation of the defendant and the episode-in-suit to the forum to determine if there is a substantial connection with the forum, as Justice Ginsburg suggests, and then would provide a the second-step assessment of the interests of the parties and the relevant states, to determine if litigation of the claim at

393. Walden v. Fiore, 134 S. Ct. 1115, 1124, 1124-26 (2014).

394. Id. at $1121-22,1125$.

395. E.g., Effron, supra note 35, at 871-72 (concluding that focus on the relation of the lawsuit to the forum would help the Court decide individual specific jurisdiction cases and that use of the "fairness factors" would put appropriate limits on specific jurisdiction); Twitchell, supra note 4, at 659 (noting that the various "interests" of the reasonableness analysis serve as "checking factors [that] will allow [a] court [] to work with a more generous definition of 'related' contacts without fearing that they will be compelled to grant jurisdiction in every case"). 
issue in the forum would be reasonable. ${ }^{396}$ The analysis would also include, as all must, a minimum background requirement, which would rarely be implicated, of whether inconvenience alone would warrant dismissal of the lawsuit. To prevail on a contention that inconvenience alone warrants due process protection, the defendant would need to make a very high showing of inconvenience, along the lines of "practical inability to defend" combined with the existence of an available alternative forum in which the plaintiff may meaningfully litigate or that the designated forum is "so manifestly and gravely inconvenient that the defendant will be effectively deprived of a meaningful day in court." 397 The defendant in Walden made no claim of such inconvenience, nor could he have established such inconvenience on the facts at issue. Indeed, the court made no assessment of the inconvenience of the forum to the defendant.

As noted, the Walden Court, in fact, conducted a simultaneous inquiry regarding the connection of the defendant and the lawsuit to the forum, but it limited analysis of each factor, thus putting artificial limits on specific jurisdiction and obscuring the Court's reasoning. If the Court examines the relatedness of the episode-in-suit to the forum and conducts an unconstrained "reasonableness" inquiry, as suggested by Justice Ginsburg, it would have to make choices, and it might eventually revisit and revise its initial choices. It is, however, this "reasonableness" inquiry that would determine the appropriate breadth of specific jurisdiction, impose appropriate limitations, and provide necessary guidance to courts. Such an analysis would reveal, in the Walden case, that defendant took intentional action in Georgia that he knew would harm Nevada residents, if at all, in Nevada. These facts would have permitted the Court to recognize that the episode-in-suit connected Walden to Nevada. Defendant Walden had "contacts, ties, or relations" with Nevada, though those connections were not extensive. The Court could then have moved to the related inquiry regarding whether it was reasonable to litigate the claim at issue in Nevada. The Supreme Court has referred to this inquiry as a "reasonableness" or "fairness" inquiry, ${ }^{398}$ and it is inquiry that would put the appro-

396. Daimler AG v. Bauman, 134 S. Ct. 746, 762 n.20 (2014); see also Effron, supra note 35 , at 871-72 (asserting that the "fairness factors" first articulated in World Wide Volkswagen would "guard against excessive exercises of jurisdiction"); Lilley, supra note 32, at 114-15 (suggesting there be a first, but minimal, requirement that defendant "could have reasonably foreseen the development of an affiliating link with the forum state" and that thereafter the court could examine the reasonableness of the forum plaintiff selected, including, as in a choice of law analysis, the relation of the transaction and the plaintiff to the forum); Twitchell, supra note 4, at 659 (concluding that all "circumstances surrounding the suit, including the nature and quality of the defendant's contacts, the nature of their relationship to the suit, the inconvenience to the defendant of defending in the forum, and, to some extent, the interests of the plaintiff, the forum, and other states" could serve as "checking factors" that permitted expansion of specific jurisdiction, but also put reasonable limits on that expansion); Woods, supra note 16, at 881-82, 890-91 (suggesting an analysis that requires (1) an initial, minimal governmental interest; (2) fair notice to the defendant; and (3) an analysis of various "fairness factors").

397. See supra note 381.

398. E.g., World-Wide Volkswagen Corp. v. Woodson, 444 U.S. 286, 292 (1980). 
priate limits on specific jurisdiction. ${ }^{399}$

Von Mehren and Trautman observed that the Supreme Court used the following factors in its early opinions to determine if specific jurisdiction were available: (1) the nature of claim, the dollar amount at issue, and the extent and nature of the defendant's and plaintiff's forum connections; (2) whether "economic activities" of the defendant or plaintiff were at issue; (3) whether the defendant was a corporation or individual, whether the defendant's "economic activities and legal involvements were pervasively multistate," and whether the defendant's activities foreseeably involved the risk of harm to people in other communities; (4) whether the plaintiff acted in a multistate or local manner; (5) the comparative ease with which the defendant could litigate in the forum and the plaintiff could litigate in defendant's home state or other alternative forum; and (6) issues regarding efficient conduct of litigation. ${ }^{400}$ The Supreme Court later reformulated those factors to include all relevant interests, including those of the parties, relevant states, and efficiency of litigation. ${ }^{401}$

In Walden, analysis of the defendant's relation to the forum would reveal that the Georgia defendant had no physical "contact" with Nevada and that the alleged constitutional violations were tightly connected to preventing drug trafficking in a Georgia airport. A more forthright analysis, i.e., one not constrained to seek only "contacts" the defendant himself created with Nevada, would acknowledge that defendant was at least minimally "connected" with Nevada because the particular episode-insuit connected him to Nevada: Walden allegedly provided to the United States Attorney a false affidavit seeking forfeiture of plaintiffs' money when he had exculpatory information and he also knew plaintiffs were residents of Nevada and, thus, knew they would be harmed, if at all, in Nevada by improper and intentional acts in Georgia to withhold their money. ${ }^{402}$ Having found a sufficient connection of the lawsuit to the forum, the Court would have moved to the second-step assessment of the reasonableness of asserting jurisdiction in Nevada over the case at issue.

In the second step, a reasonableness assessment, the Court could have determined that no interest supported personal jurisdiction. The Court could have determined that, because the claims at issue were tightly connected to airport security and prevention of drug trafficking in an Atlanta airport, Nevada had little regulatory interest in the substantive claims, while Georgia had a heightened interest in providing a forum for the substantive claims. Nevada's interest might, thus, have been limited to a

399. See supra note 396.

400. Von Mehren \& Trautman, supra note 10, at 166-69; see also supra notes 117-147.

401. Asahi Metal Indus. Co. v. Superior Court, 480 U.S. 102, 113 (1987) (quoting World-Wide, 444 U.S. at 292 and recognizing the following relevant interests: the burden on defendant in litigating in the chosen forum; the plaintiff's interest in obtaining convenient and effective relief; the state's interest in adjudicating the dispute; the interstate judicial system's interest in the most efficient resolution of the controversy; and the shared interest of the interstate judicial system in furthering fundamental substantive social policies); see also Burger King Corp. v. Rudzewicz, 471 U.S. 462, 476-77 (1985).

402. Walden v. Fiore, 134 S. Ct. 1115, 1120 (2014). 
state's ever-present interest in providing a forum for suit by its residents. Though it has been argued that permitting jurisdiction based solely on a state's interest in providing a forum to its residents could be a sufficient basis for specific jurisdiction, ${ }^{403}$ the Court has not, to date, accepted such theories. ${ }^{404}$

What of the interests of the plaintiff and defendant, the comparative assessment of the ease to the litigants of suit in Georgia as opposed to Nevada, and litigation convenience? Here, it is relevant that defendant Walden was an individual, not a corporate actor; he did not act for economic or other gain, but in the course of employment; and he acted to further national public safety interests. Indeed, the Court could have concluded that the category of substantive claims in which the defendant is a local or national law enforcement agent, who is sued in another state for actions taken in pursuit of local or national law enforcement objectives, may generally favor jurisdiction in the forum of the defendant's actions rather than in alternative forums in which nonresident plaintiffs may reside.

Plaintiffs, by contrast, certainly possessed an interest in suing in the convenient forum of their residence, but the facts reveal that it was the plaintiffs who acted in a multi-state manner and for economic gain, while the defendant in the case was the local actor. Under the analysis proposed by von Mehren and Trautman and other commentators, if one party acts in an interstate manner and the other acts in an essentially local way, the interest of the multistate actor in the home forum-here the plaintiffs - is lessened. ${ }^{405}$ On these facts, the Court could have found (1) that, as indicated above, the sole state interest in providing a forum for redress of resident's claims was insufficient on the facts at issue; (2) that, neither the interests of the defendant nor the plaintiffs supported suit in Nevada; and (3) that the comparative burden to the traveling plaintiffs or the traveling defendant-law enforcement officer regarding litigation in Nevada or Georgia favored suit in Georgia. Likewise, considerations of

403. E.g., Lilley, supra note 32 , at 115 (concluding that if a defendant could reasonably foresee the development of an affiliating link with the forum, courts should turn to an assessment of the reasonableness of the chosen forum); McDougal, supra note 92, 8-9, 13 14, 26-31 (advocating an analysis that would permit jurisdiction based on a state's interest, including the interest in providing a forum for residents to bring suit, subject to defendant's showing that the forum would impose an undue burden); Kogan, supra note 84, at 367-71 (presenting a "mutual inconvenience" paradigm for personal jurisdiction that accords little importance to state boundaries or sovereignty); see also Jay, supra note 65, at 463-64 (accepting that there may be no jurisdiction in a forum with no relation to the defendant other than that the plaintiff chose to sue there, but suggesting that usually the defendant does have some additional relation, though that may simply be that the plaintiff's move was foreseeable to the defendant, and, in such instances, the Court should explain why there is no jurisdiction).

404. E.g., Kurland, supra note 94, at 591; Note, supra note 90, at 924 (state's interest in providing a forum has been considered, alone, insufficient); Stein, supra note 35, at 417 (concluding that "the Supreme Court has made clear that an ex poste remedial interest is not enough to justify jurisdiction, [but] the ex ante [regulatory] interest is, in fact, central to the Court's conception of proper jurisdiction").

405. Von Mehren \& Trautman, supra note 10, at 1164, 1166-69. 
the location of the evidence and efficient litigation would likely have revealed that many of the witnesses and much of the evidence relating to the search at the airport and Walden's subsequent conduct was located in Georgia.

Through this type of interest analysis, the Court would have begun the business of providing guidance to lower courts regarding the factors that are important in the specific jurisdiction analysis and how to apply those factors.

In summary, the Walden Court permitted simultaneous consideration of the litigation's relation to the forum and the defendant's relation to both the forum and the plaintiff, but it considered the examined factors in isolation and limited consideration to whether each factor revealed contacts by defendant with the forum. The Court seemed to assume that, if it found a contact by the defendant with Nevada, specific jurisdiction must automatically follow. 406 That has never been the result when the Court employed a reasonableness analysis. ${ }^{407}$ Instead, the Court has undertaken an inquiry to-in the words of Judge Learned Hand, "put [] the real question,"-to determine whether "the extent and continuity of what ... [the defendant] has done in the state in question makes it reasonable to bring [him] before one of its courts." 408 This analysis would also align closely with Justice Ginsburg's statement, in dicta, in Daimler $A G$ v. Bauman regarding the nature of the specific jurisdiction inquiry: "First a court is to determine whether the connection between the forum and the episode-in-suit could justify the exercise of specific jurisdiction. Then, in a second step, the court is to consider several additional factors to assess

406. See Twitchell, supra note 4, at 658-59 (noting that a defendant's minimal forum contacts would not suffice for specific jurisdiction, but would require a focused inquiry into the fairness of the forum, based on assessment of "the nature and quality of the defendant's contacts, the nature of their relationship to the suit, the inconvenience to the defendant of defending in the forum, and, to some extent the interests of the plaintiff, the forum, and other states").

407. See, e.g., Calder v. Jones, 465 U.S. 783 (1984); Keeton v. Hustler Magazine, Inc., 465 U.S. 770 (1984); McGee v. Int'l Life Ins. Co., 355 U.S. 220 (1957); Mullane v. Ctr. Hanover Bank \& Trust Co., 339 U.S. 306 (1950); Travelers Health Ass'n v. Virginia, 339 U.S. 643 (1950).

408. Hutchinson v. Chase \& Gilbert, Inc., 45 F.2d 139, 141 (2d Cir. 1930). Pertinent factors have been variously stated by commentators. See Effron, supra note 35, at 871-72 (asserting that the "fairness factors" first articulated in World-Wide Volkswagen would "guard against excessive exercises of jurisdiction"); Lilley, supra note 32, at 114-15 (suggesting there be a first, but minimal, requirement that defendant could "have reasonably foreseen the development of an affiliating link with the forum state" and that thereafter the court could examine the reasonableness of the forum plaintiff selected, including, as in a choice of law analysis, the relation of the transaction and the plaintiff to the forum); Twitchell, supra note 4, at 658-59 (concluding that "all of the circumstances surrounding the suit, including the nature and quality of the defendant's contacts, the nature of their relationship to the suit, the inconvenience to the defendant of defending in the forum, and, to some extent, the interests of the plaintiff, the forum, and other states" could serve as "checking factors" that permitted expansion of specific jurisdiction, but also put reasonable limits on that expansion); Woods, supra note 16, at 881-82, 890-91 (suggesting an analysis that requires (1) an initial, minimal governmental interest; (2) fair notice to the defendant; and (3) an analysis of various "fairness factors"). 
the reasonableness of entertaining the case." ${ }^{409}$

\section{AN INTEREST ANALYSIS}

In the Supreme Court's four recent personal jurisdiction cases, Bauman, Goodyear, Nicastro, and Walden, the Supreme Court justices have accomplished much. They defined the "home"-based metaphor regarding general jurisdiction in a way that provides guidance to lower courts. ${ }^{410}$ They continued to fight the good fight over specific jurisdiction in instances of isolated or occasional forum contacts, replete with inability of even five justices to agree on a rationale in Nicastro. ${ }^{411}$ They then concluded, in Bauman and Walden, that, in the specific jurisdiction context, due process protects an individual liberty interest, but the Court construed the contours of the individual liberty interest differently in the two cases. ${ }^{412}$ In Bauman, the Court narrowed general jurisdiction and suggested a broader scope for specific jurisdiction. The Walden Court, likewise, used a mode of analysis for specific jurisdiction that purported to consider the "relation among the defendant, the forum, and the litigation," but Walden ultimately circumvented that analysis by examining factors regarding the defendant and the transaction, but only to determine if they revealed sufficient contacts by defendant with the forum. In these opinions, the Court used a fairness or reasonableness approach to limit general jurisdiction, but it could not then agree to extend the same theoretical approach to specific jurisdiction, with the concomitant expansion of specific jurisdiction that the reasonableness approach would entail.

In accord with the conclusions in Bauman and Walden that the "inquiry into the 'minimum contacts' necessary to create specific jurisdiction focuses on 'the relation [ ] among the defendant, the forum, and the litigation,' ${ }^{413}$ I conclude that the Court should use an analysis similar to the interest analysis it has used periodically, but has not yet refined-one that is similar to the Bauman Court's suggested approach. Bauman, in dicta, suggested a two-step analysis. In the first step, the court would determine if "the connection between the forum and the episode-in-suit could justify exercise of specific jurisdiction." ${ }^{14}$ In this analysis, the Court should require only a minimal relation between the defendant and the forum, or between the episode-in-suit and the forum. If such a minimal connection exists, the court should assess, in a second-step, the reasonableness of asserting jurisdiction over the particular claims in the forum at issue. In

409. 134 S. Ct. 746, 762 n. 20 (2014). It would also align with Justice Ginsburg's analysis in dissent in J. McIntyre Mach., Ltd. v. Nicastro, 131 S. Ct. 2780, 2798 (2011) (Ginsbrug J., dissenting).

410. See supra notes $264-279$, and accompanying text.

411. Nicastro, 131 S. Ct. 2780.

412. Walden v. Fiore, 134 S. Ct. 1115, 1122 (2014) See also Bauman, 134 S. Ct. at 753, $755,757-58$

413. Bauman, 134 S. Ct. at 754, 757-58; Walden, 134 S. Ct. at 1122.

414. Bauman, 134 S. Ct. at 760 n.20. 
this second step, the Court would examine all relevant interests, including the interests of the defendant, the plaintiff, a comparative assessment of the convenience of the forum and alternative forums for the parties at issue, and the interests of the forum state and other states, as well as interests in efficient litigation of the matter. ${ }^{415}$ If the Court concludes that jurisdiction is warranted given the relevant interests, the defendant could, of course, (1) seek a transfer of venue to obtain a more convenient forum; or (2) make the difficult argument that the forum was so inconvenient as to deny due process. ${ }^{416}$ This type of inquiry would "put the real question"- do the defendant and litigation have sufficient connection with the forum, consistent with the Due Process Clause, to make it reasonable for the parties to litigate the particular case in the particular forum?

As with International Shoe's rejection of fictitious notions of "consent" and "presence," this analysis, like the Walden analysis, would eliminate the use of purposeful availment as a fictitious proxy for unarticulated interests of the defendant or of other states. It would also, however, eliminate the artificial barrier that Walden erected to restrict jurisdiction-that "defendant's actions [must] connect him to the forum." 417

The analysis should be similar to that used in the pre-Hanson era ${ }^{418}$ and in some post-Hanson cases, including Calder v. Jones, ${ }^{419}$ Keeton v. Hustler Magazine, Inc. ${ }^{420}$ and Justice Ginsburg's similar analysis in her dissent in J. McIntyre Machinery, Ltd. v. Nicastro. ${ }^{421}$ As indicated in prior discussions of the cases in which the Court has used a similar analysis, the interest analysis will necessarily be tailored to address the varying situations provided by differing claims. Moreover, the interests would be considered simultaneously rather than permitting any one interest, for example, the defendant's, to be considered as a necessary prerequisite..$^{422}$ Thus, the inconvenience of the defendant, while always a consideration, but rarely alone sufficient to require rejection of the forum on due process grounds, ${ }^{423}$ would be minimized or strengthened in light of consideration of other relevant interests. The assessment of the connectedness of the litigation to the forum, in light of the relevant interests, would, thus, become the prime determinant of the due process inquiry in most cases.

The analysis would, moreover, permit a unified approach for all spe-

\footnotetext{
415. See supra note 408.

416. See supra note 381.

417. Walden, $134 \mathrm{~S}$. Ct. at 1124.

418. See supra notes $115-147$ and accompanying text.

419. 465 U.S. 783 (1984); see supra notes 318-325 and accompanying text.

420. 465 U.S. 770 (1984); see supra notes 327-338 and accompanying text.

421. J. McIntyre Mach., Ltd. v. Nicastro, 131 S. Ct. 2780, 2800-04 (2011) (Ginsburg, J., dissenting); see supra notes 205-206 and accompanying text.

422. See Note, supra note 90 , at 924 (noting that, in considering factors jointly, some "factors may tend to minimize the convenience to the defendant and to strengthen the interests of the plaintiff and of the state so that . . . it may not be ultimately unfair to subject the defendant to suit even in an inconvenient forum").

423. See supra notes 381 , and accompanying text.
} 
cific jurisdiction cases. ${ }^{424}$ It would, thus, eliminate problems of categorical analysis, including those problems that have emerged from reading "isolated and casual" forum contacts and "continuous and systematic" contacts to permit jurisdiction only over claims "arising out of" those contacts. Importantly, the Supreme Court has used a similar approach periodically and in various types of specific jurisdiction cases, and these cases reveal that an interest-based reasonableness analysis can be used effectively. The Court has, for instance, used the approach in instances of minimal forum contacts, ${ }^{425}$ in instances in which defendants have continuous forum contacts, but portions of the case are unconnected with the forum, ${ }^{426}$ and in instances in which the defendant's conduct outside the forum impacts forum residents. ${ }^{427}$ But this analysis should expand, from one focused primarily on the quantity of the defendant's contacts, to an analysis that focuses also on the relatedness to the forum of the claim, the episode-in-suit, and the parties.

The Court's cases involving minimal forum contacts also illustrate that this interest analysis will appropriately expand specific jurisdiction in many cases ${ }^{428}$ but it also provides for limits in appropriate cases. My application of the analysis to the Walden $v$. Fiore case, for example, reveals that the Court could have determined, in the first step of the analysis, that the "connection between the forum and the episode-in-suit could justify exercise of specific jurisdiction"-Walden allegedly drafted a false affidavit to seek forfeiture of money from plaintiffs when he possessed exculpatory information and also knew plaintiffs were located in Nevada and would suffer any harm from lack of access to the funds in Nevada. That determination would have warranted moving to the second-step a reasonableness assessment. In the second step, the Court could have determined that the interests of Nevada and plaintiffs were limited, respectively, to the state's interest in providing a forum for its residents to seek redress for claims and a plaintiff's interest in suing at home-neither of which has

424. Similarly, the Walden Court indicated that its analysis permitted intentional torts to be considered in a uniform manner, rather than as a specific and different subcategory. Walden v. Fiore, 134 S. Ct. 1115, 1123 (2014) (setting forth the specific jurisdiction analysis and concluding that "[t]hese same principles apply when intentional torts are involved").

425. E.g., Calder, 465 U.S. at 788-91 (1984); McGee v. Int'l Life Ins. Co., 355 U.S. 220 222-24 (1957); see also Asahi Metal Indus. Co. v. Superior Court, 480 U.S. 102, 113-16 (1987) (applying the following fairness factors articulated in World-Wide Volkswagen, see supra note 186, and denying jurisdiction over a foreign manufacturer of component parts on the particular facts of the case).

426. Keeton v. Hustler Magazine, Inc. 465 U.S. 770, 779-81 (1984).

427. Calder, 465 U.S. at 788-90; Travelers Health Ass'n v. Virginia, 339 U.S. 643 (1950).

428. E.g., Calder, 465 U.S. at 789-91 (finding jurisdiction appropriate over editor of article who had minimal forum contacts); McGee, 355 U.S. at 223-24; see also J. McIntyre Mach. Ltd. v. Nicastro, 131 S. Ct. 2790, 2794-97, 2800-04 (Ginsburg, J., dissenting) (concluding that jurisdiction was reasonable in the state where plaintiff was injured by the foreign defendant's allegedly defective product, where the corporate defendant treated the United States as a single, national market; targeted the United States as a whole by seeking to sell products "anywhere in the United States"; purposefully engaged a domestic distributor to sell products in any state and attended regular product exhibitions in American cities; and where the plaintiff was a local actor injured at his jobsite while using defendant's product). 
been alone or in combination sufficient to warrant jurisdiction. ${ }^{429}$ The Court could have also concluded that neither the interest of the defendant nor that of efficient conduct of litigation supported suit in Nevada and that the comparative defendant-plaintiff convenience analysis supported suit in defendant's forum. Thus, although the second-step reasonableness inquiry would not ordinarily be a demanding one, the Court could have concluded that, in Walden, no interest supported personal jurisdiction in the forum state. ${ }^{430}$

I close by listing some factors that would generally be relevant to the interest analysis. ${ }^{431}$ These factors should, of course, be developed and refined through application in differing scenarios and to differing claims, thus, suggesting that issues regarding case-type and connection of the claim to the forum should be as critical as the extent of the defendant's forum contacts. Moreover, the list illustrates that the factors interrelate, with an issue that minimizes or increases a defendant's interest often impacting the interest of the plaintiff or state.

The nature of the claim will be central to the relatedness inquiry, as Walden, Calder v. Jones, and other cases indicate, because the claim implicates the nature and strength of the forum state's regulatory interest and will often also reveal the closeness of the connection of the plaintiff or defendant to the state as well as issues of litigation efficiency. ${ }^{432}$ Both Walden and Calder, for example, involved intentional torts. Walden correctly indicated, however, that the intentional tort of libel, which includes the injury of diminution of reputation, will generally be tied closely to the state of the libel, the state of the victim of the libel, or the location of the libelous publication's dissemination, and to that state's regulatory interests. Other intentional torts (such as those related to alleged improper actions outside the forum state by law enforcement officers in the course of their work), however, may not be so connected to a particular forum or that forum's regulatory interests. ${ }^{433}$

429. See supra notes 403-404 and accompanying text.

430. See Asahi Metal Indus. Co. v. Superior Court, 480 U.S. 102, 113-16 (1987) (concluding that, even if there were sufficient forum contacts, a reasonableness analysis would reveal that asserting jurisdiction would be unreasonable under the circumstances); accord Kurland, supra note 94, at 591 acknowledging state interest in providing a forum for its inhabitants, but concluding that plaintiff's domicile or residence alone would probably not be a sufficient interest to establish personal jurisdiction); Note, supra note 90 , at 924 (state's interest in providing a forum has been considered, alone, insufficient); Stein, supra note 35, at 417 (concluding that "the Supreme Court has made clear that an ex poste remedial interest is not enough to justify jurisdiction, [but] the ex ante [regulatory] interest is, in fact, central to the Court's conception of proper jurisdiction").

431. See generally Clermont, supra note 35, at 451-55; Effron, supra note 35, at 896-903; Lilley, supra note 32, at 111-15; Twitchell, supra note 4, at 660-65; von Mehren \& Trautman, supra note 10, at 1166-76; Woods, supra, note 16, at 891-98.

432. Effron, supra note 35, at 900-03; Twitchell, supra note 4, at 662-63; Stein, supra note 35 , at 412-13 (noting that personal jurisdiction is "claim specific not transsubstantive").

433. Similarly, McGee can be construed to include concern for classes of plaintiffs with small dollar claims against out-of-state corporate insurers. McGee, 355 U.S. at 223-24. 
The defendant's interests will also be important. Among factors that would generally be relevant are the following: the nature and extent of defendant's forum contacts; whether the defendant is a business entity or natural person; whether the defendant's in-state conduct, activity, or impacts are in pursuit of economic gain or are otherwise related to the claim at issue; whether the defendant's conduct is "pervasively multistate" or "essentially local," and whether the defendant typically acts in an essentially multistate manner; whether the defendant could foresee harm to people in other communities based on its conduct; whether the defendant acted intentionally; and whether the defendant would be unfairly surprised by litigation in the forum. These issues will, in many respects and in many cases, overlap with the interests of the plaintiff and state.

Issues relevant to the plaintiff's interest will similarly include whether the plaintiff is a business entity or natural person; whether the plaintiff acted in a multistate, "pervasively multistate," or essentially local manner; whether the plaintiff acted to pursue economic interests or other interests; a comparative assessment of the ability of the defendant to litigate in the chosen forum and the plaintiff to litigate in the alternative forum; and the value of plaintiff's claim.

Issues relevant to the state's interest include the state's regulatory interest in enforcing the substantive claim at issue; the state's interest in providing a forum to residents who might otherwise be forced to litigate in distant forums; the interstate interest in efficient enforcement of litigation, including considerations of the location of witnesses and evidence; and whether the forum is one in which all defendants could be joined.

Finally, and perhaps overlapping with all of the above interests-the defendant's interest, the plaintiff's interest, and the state's interest-is the consideration of issues relevant to efficient litigation and the administration of justice. These would include issues regarding the location of witnesses and evidence, ease of applying forum law, and perhaps, in appropriate cases, whether the forum is one in which personal jurisdiction may be obtained over all defendants.

\section{CONCLUSION}

This Article examined the new approach to personal jurisdiction taken in the Supreme Court's recent opinions. The Court's opinion in Daimler $A G$ v. Bauman can be read as taking initial steps on the long journey back to restoring the aspiration of International Shoe v. Washington, in which general jurisdiction would be narrowly construed and specific jurisdiction would be determined by a flexible standard that would permit realistic assessment of the reasonableness of hailing a defendant to the particular court, given the particular claims at issue. The Court's decision in Walden v. Fiore began down this path, but ultimately turned back, implementing a one-dimensional requirement that a defendant must have sufficient forum contacts. Walden also required that any reasonableness factors considered should be examined only to determine if they revealed 
contacts by defendant with the forum. The Walden case, thus, reflects the Court's continuing ambivalence regarding specific jurisdiction.

This Article concludes that Bauman and Walden correctly premised specific jurisdiction on the "relation among the defendant, the forum, and the litigation." To implement this analysis, this Article advocates that the Court adopt an interest analysis similar to that suggested in dicta in the Bauman opinion. In a first step, a court should consider whether the episode-in-suit has at least a minimal connection with the forum. If so, a court would, in a second step, consider all relevant interests in deciding whether assertion of jurisdiction would be reasonable. This analysis would permit both general and specific jurisdiction to be analyzed under a single conceptual theory; would implement the Court's recognition in Walden and other cases that specific jurisdiction primarily protects the individual liberty interest; would permit specific jurisdiction to respond realistically to the changes in transportation and communication that have minimized the previous burden of litigation in foreign tribunals; and would ultimately provide a unified analysis for specific jurisdiction cases rather than of a series of category-specific analyses. Such a flowering of specific would provide coherence to the Court's personal jurisdiction doctrine and would give further legitimacy to its narrowing of general jurisdiction. 